\title{
13. Öğretmen görüşlerine göre salgın (COVID-19) dönemi uzaktan eğitim ortamında Türkçe eğitimi
}

\section{Kadir KAPLAN 1}

\section{Bahadır GÜLDEN²}

APA: Kaplan, K.; Gülden, B. (2021). Öğretmen görüşlerine göre salgın (COVID-19) dönemi uzaktan eğitim ortamında Türkçe eğitimi. RumeliDE Dil ve Edebiyat Araştırmaları Dergisi, (24), 233-258. DOI: $10.29000 /$ rumelide.995291.

$\ddot{O} \mathbf{z}$

COVID-19 salgını öncesinde hâlihazırda önemli bir öğrenme ortamı olan uzaktan eğitim, salgınla birlikte ilk ve ortaöğretim seviyesinde de tercih edilmiştir. Milyonlarca öğrenci ve öğretmenin ani bir şekilde karşı karşıya kaldığı uzaktan eğitim ortamının Türkçe öğretimi açısından işlevsel kılınabilmesi için güçlü ve zayıf yönlerinin ortaya çıkarılması önemlidir. Bu çerçevede uzaktan eğitimin dört temel dil becerisi başta olmak üzere çeşitli yönlerden durumuna dair Türkçe öğretmenlerinden veriler elde edilmiştir. Verilerden hareketle uzaktan eğitimle ilgili dile getirilen temel problem, öğrencilerin teknik anlamda firsat eşitliğine sahip olamamaları nedeniyle aynı oranda bu imkândan istifade edememesidir. Velilerin, öğrencilerin ve öğretmenlerin teknoloji okuryazarlı̆̆ konusunda desteklenmesinin uzaktan eğitimin işlevselliğini artıracağı uzlaşılmış bir fikirdir. Uzaktan eğitim ortamlarının daha etkin kılınması için farklı materyallerle desteklenmesi bir başka önemli husustur. Çalışmadan elde edilen verilerin ışık tuttuğu bir diğer nokta ise ölçme-değerlendirmeye yöneliktir. Uzaktan eğitim ortamının sürecin başında, ortasında ve sonunda ölçme-değerlendirme yapmaya verileri bireysel ya da kitlesel olarak karşılaştırarak daha derin analizler yapmaya imkân sağlayıcı fırsatları daha etkin bir şekilde kullanılarak değerlendirilmelidir. Eğitim Bilişim Ağı’nın bu açıdan sunduğu mevcut imkânların süreç temelli ölçme anlayışına elverişli olması bu bakımdan önemlidir. Türkçe dersi açısından uzaktan eğitimin belirli sebeplere bağlı olarak aksayan yönleri söz konusu olsa da sistemde ve paydaşların hazırbulunuşluk düzeylerinde iyileştirmeler yapıldığında uzaktan eğitim ortamının Türkçe öğretimi kazanımlarının edinilmesine son derece uygun bir zemine sahip olduğunu söylemek mümkündür.

Anahtar kelimeler: Türkçe eğitimi, temel dil becerileri, uzaktan eğitim, COVID-19

\section{Turkish education in distance education process during the epidemic period (COVID-19) according to the views of teachers}

\begin{abstract}
Distance education, which was already an important learning environment before the COVID-19 pandemic, was also preferred at the primary and secondary level with the advent of epidemic. It is important to draw attention to the points that can be improved by revealing its strengths and weaknesses in order to make this educational environment, where millions of students and teachers are suddenly confronted, more functional in terms of Turkish teaching. In this context, data were
\end{abstract}

Dr., Millî Eğitim Bakanlı̆̆ı, (Afyonkarahisar, Türkiye), kadkaplan@gmail.com, ORCID ID: oooo-ooo1-7901-1025 [Araştırma makalesi, Makale kayıt tarihi: 21.05.2021-kabul tarihi: 20.09.2021; DOI: 10.29000/rumelide.995291 Dr. Öğr. Üyesi, Bayburt Üniversitesi, Eğitim Fakültesi, Türkçe Eğitimi Bölümü (Bayburt, Türkiye), bahadirgulden@hotmail.com, ORCID ID: oooo-0003-1917-8813

Adres | Address

RumeliDE Dil ve Edebiyat Araşțrmalar Dergisi $\quad$ RumeliDE Journal of Language and Literature Studies Osmanağa Mahallesi, Mürver Çiçeği Sokak, No:14/8 $\quad$ Osmanağa Mahallesi, Mürver Çiçeği Sokak, No:14/8 Kadıköy - ISTANBUL / TURKIYE 34714 Kadıköy - ISTANBUL / TURKEY 34714 e-posta: editor@rumelide.com e-mail: editor@rumelide.com, tel: +90 505 7958124, +90 216773 o 616 phone: +90 505 7958124, +90 2167730616 
Turkish education in distance education process during the epidemic period (COVID-19) according to the views of teachers / $\mathrm{K}$. Kaplan; B. Gülden (pp. 233-258)

obtained from Turkish teachers about Turkish lessons in various aspects, especially four basic language skills during distance education. Based on the data, the main problem related to distance education is that students cannot benefit from this opportunity at the same rate because they do not have equal opportunities in technical terms. It is an agreed idea that supporting parents, students and teachers in technology literacy will increase the functionality of distance education. Supporting the distance education environments with different materials is another important issue. Another point that the data obtained from the study shed light on about measurement-evaluation. It should be ensured that the distance education environment is organized in a way that allows making measurement-evaluation at the beginning, middle and end of the process and to create deeper analyzes by comparing the data individually or collectively. In this respect, it is important that the available opportunities offered by the Education Information Network are suitable for the processbased measurement approach. Although there are disadvantages of distance education in terms of four basic language skills due to certain reasons, it is possible to say that if certain improvements are made in the system and the readiness levels of the stakeholders, the distance education environment has a very suitable environment for the acquisition of Turkish teaching target objectives. As a result only distance education, which has both advantages and disadvantages, cannot be enough. However, It is obvious that distance education will be an important complement to face-to-face education, when the deficiencies based on infrastructure are eliminated, technology literacy training is given to all stakeholders of the education process, materials which are suitable for the quality of distance education are produced, and the measurement and evaluation method is reviewed within the scope of distance education.

Keywords: Turkish education, basic language skills, distance education, COVID-19

\section{Giriş}

Geleneksel uygulamalardan farklı bir şekilde uzaktaki bir kurum ya da öğreticinin bireylere bilgi ve beceri aktarmasına uzaktan eğitim denmektedir. Başka bir ifadeyle öğretici ve öğrenci arasında yüz yüze ilişki olmadan elektronik posta, radyo, dergi, gazete ve televizyon vasitasıyla sürdürülen eğitimdir (Titmus, 1997). Uzaktan eğitim kapsamındaki faaliyetler, uygulama biçimine göre eş zamanlı ve eş zamansız olmak üzere ikiye ayrılmaktadır. Eş zamanlı; eğitim öğretici ile öğrenenlerin önceden belirlenmiş bir zamanda aktif olduğu, karşılıklı etkileşimin yüz yüze eğitime olabildiğince yaklaştırılmaya çalışıldı̆̆ı süreç iken eş zamansız eğitim ise öğretici ile öğrenenin aynı zaman diliminde aktif olamayacağı durumlarda tercih edilmekte ve ders içeriğine İnternet, elektronik posta vb. araçlarla ihtiyaç duyulduğunda erişilmektedir (Fidalgo, Thormann, Kulyk, \& Lencastre, 2020).

Tarihi geçmişi eski çağlara uzanan uzaktan eğitimin dünyadaki ilk örneğinin 1840 yllında İngiltere'de başladığı kabul edilmektedir (Kaya, 2002, s.28). İsaac Pitman, uzaktan eğitim uygulamalarıyla "steno" isimli yazı yöntemini öğrencilere yazmayı öğretmiştir. Uzaktan eğitim sürecini mektupla yürüten Pitman, İncil'deki metinleri yazmayı öğretmiş ve öğrencilerinin başarılarını da notla değerlendirmiştir. Ülkemizde ise uzaktan eğitim faaliyetlerinin 1956'da Ankara Üniversitesi Hukuk Fakültesi Banka ve Ticaret Hukuku Araştırma Enstitüsünde başladığı kabul edilmesine rağmen uzaktan eğitim çalışmaları 190o'lü yıllara dayanmaktadır. Konya'da sürgün olan Ebüzziya Tevfik Bey'in 1902-1907 ylları arasında İstanbul'da yaşayan oğlu Velid'e yazdığı mektuplarla 6 yl boyunca edebiyat dersi verdiği bilinmektedir.

Dünya üzerinde deprem, hastalık gibi toplumsal olaylar yaşanabilmekte ve yaşanan bu olaylar, küresel boyutlara vararak insanlığı olumsuz yönde etkilemektedir. 2019 yllının sonu itibarıla küresel boyutta

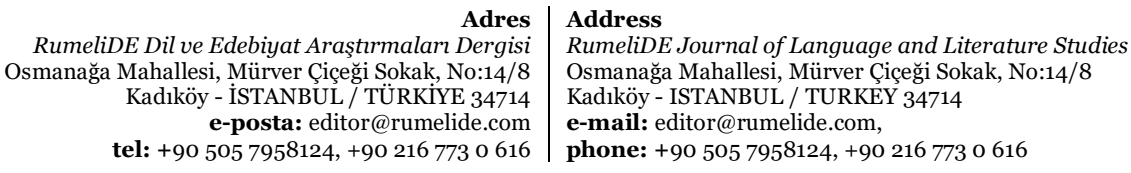


yaşanan olaylardan biri de koronavirüs salgınıdır. Yeni koronavirüs salgını, belirtileri solunum yolunda gelişen ölümcül bir virüstür. Dünya Sağllk Örgütü verilerine göre salgının birinci yılında dünya üzerinde iki milyon yedi yüz bin kişinin öldüğü koronavirüsün etkileri insan sağlı̆̆ı ile sınırlı kalmamış, salgının sosyal ve ekonomik yansımaları da olmuştur. Bütün insanlı̆̆ doğrudan ilgilendiren eğitim- öğretim faaliyetleri de süreçten fazlaca etkilenmiştir. Yüzlerce ülkede eğitim- öğretim faaliyetlerine ara verilmiş, milyonlarca öğrenci yüz yüze eğitimden uzak kalmıştır. Eğitim- öğretim faaliyetlerinin bazı gerekçelerle sekteye uğradığı dönemlerde gündeme gelen uzaktan eğitim, koronavirüs döneminde de gündeme gelmiştir. Bazı ülkeler, sahip olduğu altyapı ile kısa sürede uzaktan eğitim sürecine başlarken altyapısı yetersiz olan ülkeler ise gerekli hazırlıkları başlatma çabası içine girmiştir. Türkiye'de de virüsün yayılma hızını yavaşlatmak amacıyla 16 Mart 2020'de Millı̂ Eğitim Bakanlığı, eğitim- öğretim etkinliklerinin uzaktan eğitim sistemi ile devam etmesine karar vererek yüz yüze eğitime alternatif bir yöntem ortaya koymuştur. Kararın ardından eğitim öğretim faaliyetleri uzaktan eğitim süresince EBA TV üzerinden televizyon yayını ile ya da EBA üzerinden çevrimiçi derslerle sürdürülmüştür. Aynı şekilde YÖK de 23 Mart 2020 itibarıyla 2019-2020 öğretim yllı bahar dönemi için uzaktan eğitim kararı almıştır. Üniversiteler; bünyelerindeki uzaktan eğitim merkezleri ve farklı araçlarla çevrimiçi ve çevrimdışı dersleri yürütmüş, ölçme değerlendirmede ödev, proje, çevrimiçi sınavlar kullanılmıştır.

Alanyazında erişilebilen çalışmalar incelediğinde söz konusu çalışmaların uzaktan eğitimin yüz yüze eğitime kıyasla avantaj ya da dezavantajları ve uzaktan eğitime dair akademisyen, öğretmen, öğrenci görüşleri üzerine yoğunlaştığı görülmektedir. Çevrimiçi eğitimde yaşanan güçlüklere dair görüşleri inceleyen Edelhauser \& Lupu-Dima (2020), salgın süresince Romanya'da uzaktan eğitim gören üniversite öğrencilerinin yaşadığı problemleri irdelemiştir. Chan, So, Wong, Lee, \& Tiwari (2007), sars salgınında çevrimiçi eğitimin kaygı düzeylerini düşürdüğünü ve bilgi aktarımında etkili olduğunu ortaya koymuştur. Bawa (2016), uzaktan eğitim faaliyetlerindeki başarısızlığın yüz yüze eğitim oranla daha fazla olduğunu belirlemiştir. Eroğlu ve Kalaycı (2020), Türk Dili dersinin uzaktan ve yüz yüze eğitim ile karşılaştırmasını incelemiş ve öğrencilerin uzaktan eğitim uygulamasının içerik olarak basit ve yetersiz gördüğünü, öğretim elemanlarının etkili yöntem ve teknikler kullanmadı̆̆ını, sınavların ise basit olduğunu ifade etmiştir. Koç (2020), öğretim elemanlarının uzak eğitime dair görüşlerini topladığı araştırmada uzaktan öğrenmenin öğrenciler için eğitime erişim kolaylı̆̆ı sağladığı sonucuna varmıştır. Alpaslan (2020) ise öğretim elemanlarının görüşlerini ele aldığı çalışmasında uzaktan eğitimin bilgiye erişimde çeşitlilik sağladığını belirtmiştir.

Çevrimiçi eğitime dair görüş ve tutumları ele alan çalışmalar incelendiğinde, çalışmaların farklı disiplinlere yönelik sürdürüldüğü anlaşılmaktadır. Yılmaz (2020), Fizyoterapi ve Rehabilitasyon Bölümü öğrencilerinin uzaktan eğitime dair tutumlarını araştırmış ve uygulamalı dersler için uzaktan eğitimin geliştirilmesi gerektiği sonucuna varmıştır. Serçemeli ve Kurnaz (2020) ise uzaktan eğitim ile muhasebe dersi alan öğrencilerin görüşlerini belirlemiştir. Muhasebe eğitiminin geleneksel eğitim yöntemleriyle uzaktan eğitim yöntemlerini içerecek bir bütün halinde verilmesini önermiştir. Aktaş, Büyüktaş, Gülle ve Yıldız (2020), spor bilimleri öğrencilerinin uzaktan eğitimle işlenen derslere karşı tutumlarını incelemiştir. Öğrenciler uzaktan eğitim sistemiyle yapılan sınavların kendilerine katkı sağlamadığını ve bu süreçte öğretim elemanlarının kendilerine destek olduğunu ifade etmiştir. Mahdy (2020), salgın döneminde yürütülen çevrimiçi eğitimin veterinerlik fakültesi öğrencilerinin akademik başarılarına olan etkisini incelemiş ve öğrencilerin salt çevrimiçi eğitim sistemi ile veterinerlik becerisini kazanmalarının mümkün olmadığı sonucuna varmıştır. Keskin \& Kaya (2020), salgın dönemindeki öğrencilerin acil yapılandırılmış web tabanlı eğitim hakkındaki görüşlerini değerlendirmiştir. Yolcu (2020), sınıf öğretmenliği öğrencilerinin uzaktan eğitime yönelik deneyimlerini incelemiştir. Öğrenciler, uzaktan eğitimin olumlu yönleri kadar olumsuz yönlerinin de olduğunu belirtmiştir.

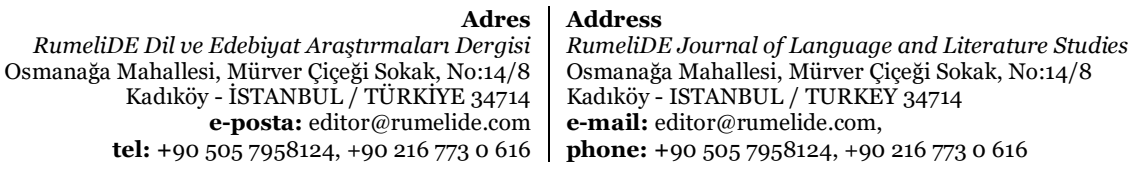


Turkish education in distance education process during the epidemic period (COVID-19) according to the views of teachers / K. Kaplan; B. Gülden (pp. 233-258)

Kocayiğit \& Uşun (2020), Millî Eğitim Bakanlığına bağlı okullarda çalışan öğretmenlerin çevrimiçi eğitime yönelik tutumlarını değerlendirmiştir. Fidan (2020), sınıf öğretmenlerinin salgın sürecinde uzaktan eğitime dair görüşlerinin olumlu ve olumsuz olarak iki boyutta toplandığını belirlemiştir. Ustabulut ve Keskin, on üniversiteden yüz elli öğrenci üzerinde yürüttüŭü çalışmada pandemi sürecinde öğrencilerin olağandışı bir teknoloji entegrasyonu ile karşı karşıya kaldığını, bu durumun da zihinsel diasporaya neden olduğunu belirtmiştir (Ustabulut \& Keskin, 2020).

Çalışmalar genel olarak değerlendirildiğinde salgın döneminde genel olarak üniversite ortamı içerisinde öğrenci ve öğretim üyelerinin görüşlerinin incelenmesine odaklanıldı̆̆ı, ortaokulda görev yapan paydaşların görüşlerine yeterince yer verilmediği görülmektedir. Bu çalışmada ise devlet ya da özel ortaokulda görev yapan Türkçe öğretmenlerinin salgın dönemindeki uzaktan eğitime ilişkin görüşleri ele alınmaya çalışılmıştır. Araştırmanın uzaktan eğitimi Türkçe öğretmenleri açısından değerlendirmesi uzaktan eğitime Türkçe dersi özelinde katkı sağlayacağı düşünülmektedir.

Yüz yüze eğitime ara verildiği dönemde uzaktan eğitim kapsamında yürütülen faaliyetler akademik anlamda ortaya çıkan eksikliği giderse de sosyal, psikolojik, pedagojik birtakım sorunlar ortaya çıkarmıştır. Bu sorunların Türkçe dersi özelindeki durumunu ortaya koymak, uzak eğitim kapsamında yürütülen Türkçe derslerinin etkililiğini ve sınırlılığını tespit etmek çalışmanın amacıdır. Bu bağlamda çalışmanın problem cümlesi, “Türkiye'de 2020 yllında salgın sebebiyle uzaktan eğitim ile sürdürülen Türkçe dersine yönelik öğretmen görüşleri nelerdir?” şeklinde ifade edilebilir. Problem cümlesinden hareketle aşağıda belirtilen alt problemlere cevap aranmıştır:

1. Daha önce herhangi bir çevrimiçi ortamda (EBA, Zoom vb.) ders anlatma tecrübeniz var mı?

2. Çevrimiçi eğitim alırken hangi araç ya da araçları kullanıyorsunuz?

3. Çevrimiçi eğitim alırken en çok karşılaştığınız sorun nedir?

4. Çevrimiçi eğitim sürecine öğrencilerinizin ilgisini ve katılımını yeterli buluyor musunuz?

5. Çevrimiçi eğitim sürecine velilerinizin ilgisini ve desteğini yeterli buluyor musunuz?

6. Çevrimiçi eğitimin sosyalleşmenize ne derecede katkısı olduğunu düşünüyorsunuz?

7. Çevrimiçi eğitimin teknoloji okuryazarlığınıza ne derecede katkısı olduğunu düşünüyorsunuz?

8. Çevrimiçi eğitimin motivasyonunuz üzerinde ne derecede etkili olduğunu düşünüyorsunuz?

9. Çevrimiçi eğitimin dinleme becerisi üzerinde nasıl bir etkisi olduğunu düşünüyorsunuz?

10. Çevrimiçi eğitimin konuşma becerisi üzerinde nasıl bir etkisi olduğunu düşünüyorsunuz?

11. Çevrimiçi eğitimin okuma becerisi üzerinde nasıl bir etkisi olduğunu düşünüyorsunuz?

12. Çevrimiçi eğitimin yazma becerisi üzerinde nasıl bir etkisi olduğunu düşünüyorsunuz?

13. Çevrimiçi eğitimin (online eğitim) öğrencilerin Türkçe dersine olan tutumlarında olumlu ya da olumsuz bir değişikliğe neden olduğunu düşünüyor musunuz?

14. Çevrimiçi eğitimin (online eğitim) dört temel dil becerileri üzerindeki olumsuz etkisini ortadan kaldırmak için neler yapılabilir?

15. Çevrimiçi eğitimin (online eğitim) iş yükünüzü artırdığını düşünüyor musunuz?

16. Salgın koşulları ortadan kalksa da çevrimiçi eğitimin (online eğitim) eğitim sisteminin bir parçası konumunda kalmasını istiyor musunuz?

17. Çevrimiçi eğitimin (online eğitim) LGS Türkçe başarısını ne yönde etkileyeceğini düşünüyorsunuz?

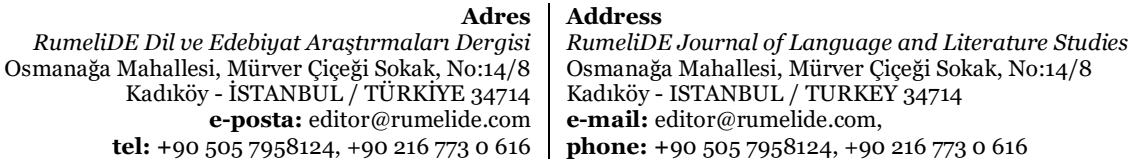

RumeliDE Dil ve Edebiyat Araşttrmalar Dergisi el: +90 $5057958124,+902167730616$

phone: +90 505 7958124, +90 2167730616 


\section{Yöntem}

\section{Araştırmanın modeli}

Araştırmada nitel araştırma yöntemlerinden durum çalışması kullanılmıştır. Durum çalışması, araştırmacının gerçek yaşam, güncel sınırlı bir durum ya da belli bir zaman içerisindeki çoklu sınırlandırılmış sistemler hakkında gözlemler, mülakatlar, görsel-işitsel materyaller ve dokümanlar ve raporlar yoluyla detaylı ve derinlemesine bilgi topladığı nitel bir yaklaşımdır (Creswell, 2013:97). Bu araştırmada Afyonkarahisar'daki bir grup Türkçe öğretmeninin uzaktan eğitim süreci hakkında görüşlerine başvurulmuş ve süreç tüm yönleriyle kapsamlı bir şekilde değerlendirilmeye çalışllmıştır.

\section{Örneklem / Araştırma grubu}

Katılımcılar, 2020-2021 eğitim-öğretim yılında Afyonkarahisar ilinde COVID-19 sebebiyle yürütülen uzaktan eğitim sürecinde aktif olarak yer alan Türkçe öğretmenlerinden oluşmaktadır. Araştırmanın çalışma grubu kolay ulaşılabilir durum örneklemesine göre belirlenmiştir. Bu yöntem diğer örnekleme yöntemlerinin kullanımının mümkün olmadığı durumlarda araştırmacıya pratiklik kazandırmak için tercih edilmektedir (Yıldırım \& Şimşek, 2018). Salgın döneminde yüz yüze iletişimin pek mümkün olmaması nedeniyle katılımcılara daha hızlı bir şekilde ulaşmak adına kolay ulaşılabilir durum örneklemesi kullanılmıştır. Araştırmada gönüllülük esası ile çalışmaya katkı verme ve uzaktan eğitim ile Türkçe dersi verme olmak üzere temel iki kriter belirlenmiştir. Katılımcıların demografik özelliklerine ait veriler Tablo 1'de yer almaktadır.

Tablo 1. Örneklem grubundaki öğretmenlerle ilgili bilgiler

\begin{tabular}{|c|c|c|c|}
\hline \multicolumn{2}{|l|}{ Demografik Özellik } & \multirow{2}{*}{$\frac{N}{14}$} & \multirow{2}{*}{$\frac{\%}{66,7}$} \\
\hline & Kadın & & \\
\hline \multirow[t]{3}{*}{ Cinsiyet } & Erkek & 7 & 33,3 \\
\hline & Toplam & 21 & 100 \\
\hline & Devlet Okulu & 20 & 95,2 \\
\hline \multirow[t]{4}{*}{ Çalışılan Kurum Türü } & Özel Okul & 1 & 4,8 \\
\hline & Toplam & 21 & 100 \\
\hline & 1-5 Yil & 1 & 4,8 \\
\hline & 6-10 Yil & 5 & 23,8 \\
\hline \multirow[t]{3}{*}{ Meslekî Tecrübe } & 11-15 Yil & 10 & 47,6 \\
\hline & 16-20 Yll & 4 & 19 \\
\hline & 20 Yll ve Üzeri & 1 & 4,8 \\
\hline \multirow{2}{*}{ Eğitim Durumu } & Lisans & 14 & 66,7 \\
\hline & Yüksek Lisans & 7 & 33,3 \\
\hline & 1-3 Saat & 3 & 14,3 \\
\hline & 4-7 Saat & 15 & 71,4 \\
\hline & 7 Saat ve Üzeri & 3 & 14,3 \\
\hline $\begin{array}{r}\text { Adres } \\
\text { RumeliDE Dil ve Edebiyat Arasttrmaları Dergisi } \\
\text { Osmanağa Mahallesi, Mürver Cicçĕgi Sokak, No:14/8 } \\
\text { Kadıköy - İSTANBUL / TÜRKIYE } 34714 \\
\text { e-posta: editor@rumelide.com } \\
\text { tel: }+90 \text { 505 7958124, +90 216 } 773 \text { o } 616\end{array}$ & \multicolumn{3}{|c|}{$\begin{array}{l}\text { Address } \\
\text { RumeliDE Journal of Language and Literature Studies } \\
\text { Osmanağa Mahallesi, Mürver Çiçeği Sokak, No:14/8 } \\
\text { Kadlköy - ISTANBUL / TURKEY } 34714 \\
\text { e-mail: editor@rumelide.com, } \\
\text { phone: +90 505 7958124, +90 } 216773 \text { o } 616\end{array}$} \\
\hline
\end{tabular}


Tablo 1'de görüldüğ̈̈ gibi çalışmaya katılan 21 öğretmenin \%66,7'si kadın iken \%33,3’ü erkektir. Çalışma grubundaki öğretmenlerin \%95,2'si devlet okulunda görev yaparken \%4,8’i ise özel okulda görev yapmaktadır. Çalışma grubunda yer alan öğretmenlerin \%47,6'lık bölümü meslekî tecrübe olarak 11-15 yl aralığındayken onları sırasıyla \%23,8 ile 6-10 yll, \%19 ile 16-20 yll, \%4,8 ile 1-5 yll ve 25 yll ve üzeri gruplar takip etmektedir. Çalışma grubundaki öğretmenlerin eğitim durumları incelendiğinde \%66,7'si lisans mezunu iken \%33,3’ü yüksek lisans mezunu durumundadır.

\section{Veri toplama araçları}

Araştırmada veri toplama aracı olarak 23 soruluk anket formu kullanılmıştır. Anketler, özellik itibarıyla hem açık uçlu hem de çoktan seçmeli soru sormaya imkân vermektedir. Anketin ilk 5 sorusu çalışma grubunda yer alan katılımcıların demografik bilgilerine ait sorular iken kalan 18’i ise 4'ü çoktan seçmeli 14’ü açık uçlu olmak üzere katılımcıların uzaktan eğitime dair görüşlerini sorgulayan sorulardır.

\section{Verilerin toplanması}

Araştırma kapsamındaki veriler, çalışma grubunda yer alan katılımcılardan salgın sebebiyle Google Forms üzerinden çevrimiçi form yoluyla alınmıştır. Çevrimiçi formun öncesinde katılımcılara çalışmanın amacına ve önemine dair açıklama yapılmış ve alınacak yanıtların gizliliği konusunda bilgi verilmiştir.

\section{Verilerin analizi}

Araştırmanın bulguları yarı yapılandırılmış görüşme formunda yer alan sorular doğrultusunda kategorilere ayrılarak incelenmiş ve sırasıyla sunulmuştur. Çalışma grubunda yer alan öğretmenlerin görüşlerinden doğrudan alıntılar yapılarak araştırma bulgularının güvenilirliği desteklenmiştir. Verilerin analizinde içerik analizi kullanılmıştır. Katılımcıların sorulara verdiği cevaplar detaylı bir şekilde incelenmiş, veriler betimsel analiz ile yorumlanmıştır.

\section{Geçerlik ve güvenirlik}

Hazırlanan sorular, 2'si Türkçe Eğitimi, 1'i Ölçme Değerlendirme Anabilim dalı uzmanı olmak üzere 3 farklı alan uzmanının görüşüne sunulmuştur. Alınan dönütlerle son şekli verilen anket formu çalışma grubu ile benzer özellikler taşıyan 3 Türkçe öğretmenine pilot uygulama kapsamında uygulanmıştır. Pilot uygulama sonucu anket formunun araştırmaya katılacak öğretmenler tarafından anlaşılabilir olduğu kanaatine varılmıştır. Anket formunun hazırlanışında uzaktan eğitim sürecinde Türkçe eğitiminin durumunu ve Türkçe öğretmenlerinin karşılaştığı sorunları ortaya koyması hedeflenmiştir.

Çalışma grubunda yer alan Türkçe öğretmenleri Ö1, Ö2... şeklinde kodlanmış ve etik ilkelerine özen gösterilmiştir. Elde edilen veriler, araştırmacılar tarafından gözden geçirilmiş, verilerinin tutarlı olduğu görülmüştür.

\section{Bulgular}

Araştırmada elde edilen veriler ışığında ulaşılan bulgular, alt problem sırası dikkate alınarak belirtilmiştir.

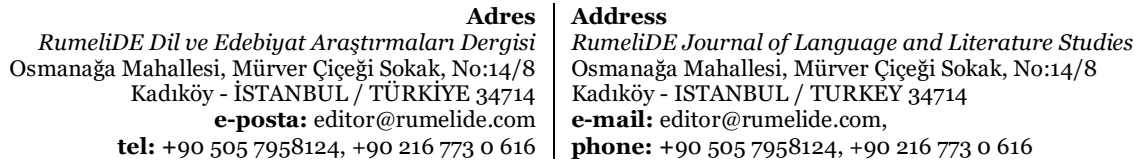
tel: $+905057958124,+902167730616$ 


\section{Birinci alt probleme ilişkin bulgular}

Katılımcıların günlük uzaktan eğitime ayırdıkları sürelerin dağılımı Tablo 2'de gösterilmiştir:

Tablo 2. Günlük ortalama uzaktan eğitime ayrllan süre

\begin{tabular}{ll}
\hline Süre & N \\
\hline $1-3$ Saat & 3 \\
4-7 Saat & 15 \\
7 Saat ve Üzeri & 3 \\
\hline
\end{tabular}

Katılımcıların 15’i günlük ortalama 4-7 saat arası uzaktan eğitime zaman ayırdığını dile getirirken üçer katılımcı ise uzaktan eğitime ortalama 1-3 ya da 7 saat üzeri zaman ayırmaktadır. Öğretmenlerin haftalık ders saati süreleri ve verdikleri cevaplar dikkate alındığında öğretmenlerin büyük çoğunluğunun uzaktan eğitim sürecinde üzerine düşen sorumluluğu ders saati anlamında yerine getirdiğini söylemek mümkündür.

\section{İkinci alt probleme ilişkin bulgular}

Katılımcıların uzaktan eğitim ile ders anlatma tecrübesine dair detaylar Tablo 3’te gösterilmiştir:

Tablo 3. Uzaktan eğitim ders anlatma tecrübesi

\begin{tabular}{ll}
\hline Tecrübe & $\mathrm{N}$ \\
\hline Evet & 2 \\
Hayır & 19 \\
\hline
\end{tabular}

Çalışmaya katkı sağlayan öğretmenlerin 19'u daha önce uzaktan eğitim ile ders anlatma tecrübesi olmadığını belirtirken sadece 2 öğretmen, daha önce çevrimiçi ortamda ders anlattığını ifade etmiştir. Öğretmenlerin uzaktan eğitime dair herhangi bir hizmet içi kurs almadan doğrudan sistemin bir parçası olması birtakım sıkıntılara sebebiyet vermiştir. Söz konusu cevaplar irdelendiğinde öğretmenlerin salgın sürecine çevrimiçi eğitim anlamında donanımsız ve hazırlıksız yakalandığı açıkça görülmesine rağmen kısa sürede yaşanan duruma reaksiyon gösterip öğrencilerine faydalı olmaya çalıştıkları da yadsınamaz bir gerçektir. Eğitimin uzaktan eğitimle farklı bir boyut kazanması eğitime yönelik yeni, farklı ve sistematik yaklaşımların geliştirilmesini zorunlu kılmaktadır.

\section{Üçüncü alt probleme ilişkin bulgular}

Katılımcıların uzaktan eğitim sırasında kullandığı araçlara dair detaylar Tablo 4’te gösterilmiştir:

Tablo 4. Kullanılan uzaktan eğitim araçları

\begin{tabular}{ll}
\hline Çevrimiçi Ĕgitim Aracı & N \\
\hline EBA, Zoom, Whatsapp ve Google Meet & 2 \\
EBA, Zoom ve Whatsapp & 9 \\
EBA ve Zoom & 9 \\
Microsoft Teams & 1 \\
\hline
\end{tabular}

\footnotetext{
Adres | Address

RumeliDE Dil ve Edebiyat Araştırmaları Dergisi Osmanağa Mahallesi, Mürver Çiçeği Sokak, No:14/8 Kadıköy - ISTANBUL / TÜRKIYE 34714 e-posta: editor@rumelide.com tel: +90 505 7958124, +90 2167730616

RumeliDE Journal of Language and Literature Studies

Osmanağa Mahallesi, Mürver Çiçeği Sokak, No:14/8

Kadıköy - ISTANBUL / TURKEY 34714

e-mail: editor@rumelide.com,

phone: +90 5057958124, +90 2167730616
} 
Uzaktan eğitim sırasında hangi araçları kullandıklarını sorduğumuz katılımcıların 9'u "EBA ve Zoom" kullandığını, 9'u bunlara ilave olarak "WhatsApp"ı da kullandığını belirtmiştir. 2 öğretmen de "EBA, Zoom, WhatsApp ve Google Meet" kullandığını ifade ederken 1 öğretmen ise "Microsoft Teams" kullandığını belirtmiştir. Verilen cevaplardan hareketle Millî Eğitim Bakanlı̆̆ının uzak eğitim faaliyetlerini "Zoom ve EBA" üzerinden yürütmesinin etkisiyle öğretmenlerin daha çok bu araçları kullandığı, bu araçların yetersiz kaldığı durumlarda da "WhatsApp" tan yararlandığı anlaşılmaktadır.

\section{Dördüncü alt probleme ilişkin bulgular}

Katılımcıların uzaktan eğitim sırasında karşılaştıkları sorunlara dair detaylar Tablo 5’te gösterilmiştir:

Tablo 5. Karşılaşılan sorunlar

\begin{tabular}{lc}
\hline Sorunlar & $\mathrm{N}$ \\
\hline Yüz yüze eğitimdeki kadar defter, kitap vb. materyallerden faydalanamamak. & 1 \\
$\begin{array}{l}\text { Yüz yüze eğitimdeki gibi öğrencilerin derste aktif olmaması, isteksiz davranması. İsteksiz } \\
\text { öğrencilerin tespitindeki zorluk. }\end{array}$ & 3 \\
Öğrencilerden sağlıklı dönüt alamama sebebiyle kendi kendine ders anlatıyor gibi hissetmek. & 3 \\
$\begin{array}{l}\text { Öğrencilerin çeşitli sebeplerle derse katılmaması/katılamaması ya da katılır gibi yapıp ortamı terk } \\
\text { etmesi }\end{array}$ & 12 \\
$\begin{array}{l}\text { Yüz yüze eğitimdeki gibi hareket ederek ders anlatamamak, sürekli oturarak ders anlatmak zorunda } \\
\text { kalmak. }\end{array}$ & 1 \\
$\begin{array}{l}\text { Birebir öğrenciyle göz teması kuramamak } \\
\text { İnternet bağlantısında yaşanan teknik sorunlar }\end{array}$ & 2 \\
\hline
\end{tabular}

Katılımcıların uzaktan eğitim sırasında yaşadığı sorunlar farklılık gösterse de yaşanan sorunların temel de iki noktada toplandığı görülmektedir. Bunlardan ilki öğrencilerin farklı sebeplerle derse katılamaması ya da aktif olarak katılmaktan kaçınmasıdır. Diğer sorun da İnternet bağlantısında ya da EBA altyapısında yaşanan teknik sorunlardır. Bunun yanında öğrencilerin aktif katılamaması, öğretmenlerin öğrenciden dönüt alamaması da diğer sorunlar arasındandır. Ortaya konan sorunlar incelendiğinde sosyoekonomik eşitsizliklerin getirdiği farklılıklar sebebiyle ortaya çıkan devamsızlık sorunları, öğrenci sayısının fazlalığı ve İnternet alt yapısındaki yetersizlikler nedeniyle ortaya çıan bağlantı sorunları ön plandadır.

\section{Beşinci alt probleme ilişkin bulgular}

Katılımcıların uzaktan eğitime öğrenci ilgi ve katılımlarına dair görüşleri Tablo 6'da gösterilmiştir:

Tablo 6. Öğrenci ilgi ve katılımı

\begin{tabular}{ll}
\hline İlgi ve Katılım & N \\
\hline Evet & 4 \\
Hayır & 16 \\
Sinıf Özelinde Değişmekte & 1 \\
\hline
\end{tabular}

\footnotetext{
RumeliDE Dil ve Edebiyat Araştırmaları Dergisi Osmanağa Mahallesi, Mürver Çiçeği Sokak, No:14/8 Kadıköy - ISTANBUL / TÜRKIYE 34714 e-posta: editor@rumelide.com tel: +90 $5057958124,+902167730616$

Address

RumeliDE Journal of Language and Literature Studies

Osmanağa Mahallesi, Mürver Çiçeği Sokak, No:14/8

Kadıköy - ISTANBUL / TURKEY 34714

e-mail: editor@rumelide.com,

phone: +90 5057958124, +90 2167730616
} 
Katılımcıların 16'sı uzaktan eğitim sürecinde öğrencilerin eğitim öğretim faaliyetlerine katılımını yetersiz bulmaktadır. Buna karşın 4 öğretmen öğrencilerin bu süreçteki katılımını yeterli görmüştür. 1 öğretmen ise öğrenci katılımının sınıftan sınıfa değiştiğini belirtmiştir.

Cevaplar değerlendirildiğinde öğrencilerin sosyoekonomik özelliklerindeki değişkenliğin verilen cevaplara yansıdığı söylenebilir. Sosyoekonomik farklılık sebebiyle her öğrencinin evinde gerekli eğitim ortamını sağlaması, ihtiyaç duyulan materyal ve donanımı temin etmesi güçleşebilmektedir. Bu durum öğrencinin çevrimiçi derslere katılımını doğrudan etkilemektedir. Millı̂ Eğitim Bakanlığı tarafından öğrencilere EBA'ya için 8 gb İnternet paketi tanımlanması, teknolojik aleti olmayanlara yönelik kampanyalar yapılmasına rağmen süreç içerisinde pek çok öğrenci ve veli mağduriyet yaşamıştır.

\section{Altıncı alt probleme ilişkin bulgular}

Katılımclların uzaktan eğitime veli ilgi ve desteğine dair görüşleri Tablo 7’de gösterilmiştir:

Tablo 7. Veli ilgi ve desteği

\begin{tabular}{ll}
\hline İlgi ve Destek & $\mathrm{N}$ \\
\hline Evet & 4 \\
Hayır & 16 \\
Veli Özelinde Değişmekte & 1 \\
\hline
\end{tabular}

Çalışmaya katılan öğretmenlerin 16'sı süreçteki veli desteğini yetersiz görürken 4 öğretmen, yeterli veli desteğini aldığını düşünmektedir. 1 öğretmen ise bu durumun veliden veliye değiştiğini dile getirmiştir.

Eğitim- öğretim faaliyetlerinin değerli bir aktörü olan velilerin salgın sürecinde eğitimin bir paydaşı olarak aktif sorumluluk al(a)mamasının eğitim- öğretim faaliyetlerinde hedeflenen amaçlara ulaşılmasında önemli bir etkendir. Velilerin teknoloji okuryazarlığı kapsamında bilgilendirilmesi ve açılacak kurslarla desteklenmesi, uzaktan eğitimin verimi için önemlidir.

\section{Yedinci alt probleme ilişkin bulgular}

Katılımcıların uzaktan eğitimin bireysel anlamdaki sosyalleşmelerine olan katkısına dair görüşleri Tablo 8'de gösterilmiştir:

Tablo 8. Kişisel sosyalleşmeye olan katkı

\begin{tabular}{lc}
\hline Kişisel Sosyalleşmeye Katkıya Dair Görüş & $\mathrm{N}$ \\
\hline & 4 \\
Uzaktan da olsa salgın sürecinde çeşitli yollarla öğrencilerle bir etkileşimde bulunarak sosyalleştim. & 4 \\
Çok az katkısı olduğunu düşünüyorum. & 2 \\
Katkısı olduğunu düşünmüyorum. Aksine olumsuz etkilediğini düşünüyorum. & 15 \\
\hline
\end{tabular}

Çalışmaya katılan öğretmenlerin 15’i salgın döneminde kişisel sosyalleşmelerinin olumsuz etkilendiğini düşünürken 4 öğretmen bu süreçte sosyalleşmenin desteklendiğini düşünmektedir. 2 öğretmen ise uzaktan eğitimin sosyalleşmesine az da olsa katkısı olduğunu dile getirmektedir. Katılımcıların cevaplarından yapılan alıntılar:

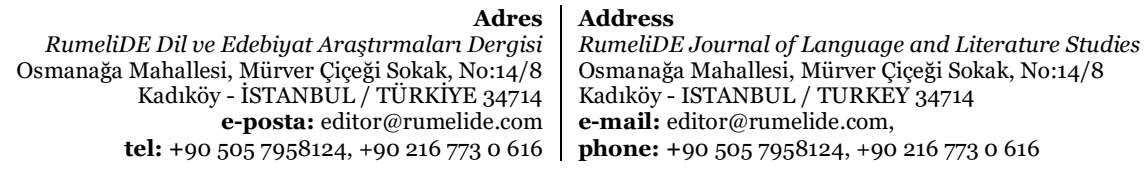


Turkish education in distance education process during the epidemic period (COVID-19) according to the views of teachers / K. Kaplan; B. Gülden (pp. 233-258)

"Olumlu bir katkısı olmamaktadır. Günün herhangi bir diliminde yapılan dersler, öncesi veya sonrasında bir şeyler yapma imkânımı azaltmakta, sadece ekran karşısında öğrencilerle kurulan diyaloglar da kişisel sosyalleşme için yeterli gelmemektedir.”(Ö,1).

"Dijital ortamda ders anlatma özgüvenim gelişti, çocuklarla iletişimimiz daha da güçlendi. Uzaktan da olsa salgin sürecince öğrencilerle bir etkileşimde bulunmak iyi geliyor bana.”(Ö,11).

"Uzaktan eğitim sosyalleşmeye katkı sağlamamaktadır. Tamamen ekrana ve eve bağh kaldık. Sosyal yaşantımı bitti.” $(\ddot{O}, 19)$.

Katılımcılar, yaşanan süreçte yoğunluk sebebiyle bireysel olarak sosyalleşemediklerini ancak sosyal ortamda öğrencilerle iletişimi sürdürerek sosyalleşebildiklerini ifade etmektedir.

Öğretmenlerin sosyalleşme kavramına bakış açısındaki farklılıklar dikkat çekmektedir. Salgın sürecinde yürütülen uzaktan eğitim faaliyetleri dijital sosyalleşmeye firsat tanımasına rağmen ders sürecinin yoğunluğu, sosyalleşme önünde engel durumundadır.

\title{
Sekizinci alt probleme ilişkin bulgular
}

Uzaktan eğitimin teknoloji okuryazarlığına katkısına dair katılımcı görüşleri Tablo 9'da gösterilmiştir:

Tablo 9. Teknoloji okuryazarlığına olan katkı

\begin{tabular}{ll}
\hline Teknoloji Okuryazarlığına Katkıya Dair Görüş & $\mathrm{N}$ \\
\hline Katkısı olduğunu düşünüyorum. & 19 \\
Herhangi bir katkısı olduğunu düşünmüyorum. & 2 \\
\hline
\end{tabular}

Çalışmaya katılan öğretmenlerin büyük çoğunluğu uzaktan eğitimin kişisel teknoloji okuryazarlıklarına katkı sağladığını düşünürken 2 öğretmen ise uzaktan eğitimin kendisine teknoloji okuryazarlığı anlamında katkı sağlamadığını belirtmektedir. Cevaplardan alınan doğrudan alıntılar aşağıda verilmiştir:

\begin{abstract}
“Bu süreçte dersi nasıl anlatacağımızı, teknolojik ürünleri nasıl ve hangi amaçla kullanacağımızı ögrendik. Tablet, grafik tablet gibi şimdiye kadar kullanmadiğımız teknolojik ürünleri derste nasıl kullanacağımızı öğrendik. Bu nedenle katkısı olduğunu düşünüyorum.” (Ö,1).

"Bu tür teknolojileri derslerde kullanma zorunluluğu, öğrencilere verimli ve ilgi çekici dersler sunma isteğiyle bu alandaki becerilerimi geliştirmemi sağlad. Rehberlik edebilmek için önce bir şeyleri öğretmenin kendisinin bilmesi gerekiyor sonuçta.” $(\ddot{O}, 2)$.

"Çevrimiç̧i eğitimde teknolojiyi daha etkili kullandığımı, farklı çalışmalardan yararlanabildiğimi fark ettim. Katkısı olduğunu düşünüyorum; çünkü öğrencilerle uzaktan eğitim için çeşitli yöntemler öğrenmek kullanmak durunda kaldık.” $(O,, 5)$.

"Bizim insanımız iş başa düşünce yapar. Ben de zora düşünce yaptım. Bu nedenle katkısı olmadığını düşünüyorum.” $(O ̈, 8)$.
\end{abstract}

Öğretmenler, süreç içinde uzaktan eğitim faaliyetlerini sürdürebilmek için daha önce kullanmadıkları uzaktan eğitim araçlarını tanıma ve kullanma fırsatı bulduklarını belirtmiştir. Az sayıdaki öğretmen ise salgın sürecinin teknoloji okuryazarlığına herhangi bir katkısı olmadığını düşünmektedir. Cevaplar değerlendirildiğinde salgın döneminde öğrencilerine faydalı olmak, eğitim- öğretim faaliyetlerini sürdürmek amacıyla öğretmenlerin uzaktan eğitim araçlarıyla ilgili bilgi ve tecrübelerini artırdıkları anlaşılmaktadır.

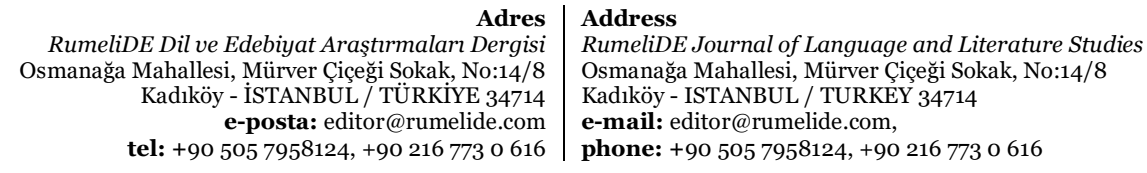




\section{Dokuzuncu alt probleme ilişkin bulgular}

Uzaktan eğitimin bireysel motivasyonları üzerindeki etkisine dair katılımcıların görüşleri Tablo 10'da gösterilmiştir:

Tablo 10. Kişisel motivasyona olan etki

\begin{tabular}{ll}
\hline Kişisel Motivasyona Etkiye Dair Görüş & $\mathrm{N}$ \\
\hline Motivasyonumu etkilemediğini düşünüyorum & 6 \\
Olumsuz etkilerinin fazla olduğunu düşünüyorum. & 11 \\
Az da olsa etkilediğini düşünüyorum. & 4 \\
\hline
\end{tabular}

Çalışma grubunda yer alan öğretmenlerin 11’i salgın sürecinde kişisel motivasyon kaybı yaşadığını belirtmektedir. 4 öğretmen, az da olsa etkilendiğini dile getirirken 6 öğretmen süreçten etkilenmeden eğitim- öğretim faaliyetlerine devam ettiğini ifade etmiştir. Verilen cevaplardan yapılan alıntılar:

"Derse, konuya, öğrenci talebine göre değişebilmektedir. Katılımın ve öğrenci katkısının yüksek olduğu dersler, öğretmen için de motive edici oluyor.” (Ö,3).

"Salgınm kişisel motivasyonumu etkilemediğini düşünüyorum. Dersleri yüz yüze eğitimde olduğu gibi istekle işliyorum.” $(\ddot{O}, 4)$.

"Öğretmen olarak motivasyon konusunda yüz yüze eğitimde olduğu kadar motive olduğumu düşünmüyorum.” $(\ddot{O}, 5)$.

"Başlangıçta etkilensem de online ders yaparak da başarılı olabileceğimi gördüğümde motivasyonum daha da arttı.” $(\ddot{O}, 6)$.

"Motivasyonumu düşürdüğüne inanıorum. Dersler saman gibi ne tadı var, ne tuzu. Açıkçası ben keyif almıorum.” (Ö,11).

“Çevrimiçi eğitimde oldukça geriliyorum, bu da beni olumsuz etkiliyor. Motive olurken zorlaniyorum.” $(\ddot{O}, 18)$.

"Motivasyonum düşük; çünkü derse katılım az oluyor. Özellikle katılım az olduğu zaman motivasyon düşüyor.” $(O ̈, 16)$.

“Etkilenmem ben. Öğrenciler karşımdaysa her ortamda işimi yapartm.”(Ö,21).

Yüz yüze eğitimde aldıkları meslekî tatmine uzaktan eğitimde erişememeleri sebebiyle öğretmenler, kişisel olarak motivasyon kaybı yaşadıklarını dile getirirken hiçbir değişkenden etkilenmeden görevini sürdüren öğretmenler ise öğrencinin varlığının kendisi için yeterli olduğunu ifade etmektedir.

Öğretmenlerin motivasyon kaybı anlamında ikiye ayrıldıkları görülmektedir. Kişisel motivasyonunu yitiren grubun yanı sıra süreçten etkilenmeden görevini sürdüren öğretmenler de bulunmaktadır.

\section{Onuncu alt probleme ilişkin bulgular}

Uzaktan eğitimin öğrencilerin dinleme becerileri üzerindeki etkisine dair katılımcı görüşleri Tablo 11'de gösterilmiştir:

Tablo 11. Dinleme becerisine olan etki

\begin{tabular}{ll}
\hline Dinleme Becerisine Etkiye Dair Görüş & N \\
\hline Olumsuz etkilediğini düşünüyorum. & 12 \\
Olumlu etkilediğini düşünüyorum. & 2
\end{tabular}

\footnotetext{
Adres Address

RumeliDE Dil ve Edebiyat Araştırmaları Dergisi $\quad$ RumeliDE Journal of Language and Literature Studies Osmanağa Mahallesi, Mürver Çiçeği Sokkak, No:14/8 $\quad$ Osmanağa Mahallesi, Mürver Çiçeği Sokak, No:14/8 Kadıköy - İSTANBUL / TÜRKIYE 34714 Kadıköy - ISTANBUL / TURKEY 34714 e-posta: editor@rumelide.com e-mail: editor@rumelide.com, tel: +90 505 7958124, +90 2167730616 phone: +90 505 7958124, +90 2167730616
} 
Turkish education in distance education process during the epidemic period (COVID-19) according to the views of teachers / K. Kaplan; B. Gülden (pp. 233-258)

Dinleme becerisi üzerinde herhangi bir etkisinin olduğunu düşünmüyorum.

1

Fikrim yok.

Duruma göre değişmekte

Çalışma grubunda yer alan katılımcıların 12'si yüz yüze derslerle kıyasladığında uzaktan eğitim süresince dinleme becerisinin olumsuz etkilendiğini düşünmektedir. 4 katılımcı, konu ile ilgili fikri olmadığını beyan ederken 2 katılımcı, çoğunluğun aksine uzaktan eğitimin dinleme becerisini olumlu etkilediğini ifade etmektedir. 2 katılımcı, olumlu ya da olumsuz etkinin duruma göre değiştiğinin altını çizmiş, 1 katılımcı ise uzaktan eğitimin dinleme becerisi üzerinde olumlu ya da olumsuz etkisinin bulunmadığını belirtmiştir.

"Bu süreç öğrencilerdeki dinleme becerisi eksikliğini görmemizi sağlamıştır. 7, 8.sınıf gibi kendini kontrol edebilen öğrencilerde sorun olmazken 5, 6.sınf gibi küçük yaş grubundaki öğrencilerin olduğu sınıflarda sıkıntıya sebep olmaktadır. Kendine odakl, sürekli kendisi konuşmak isteyen öğrencilerin öğretmeni de arkadaşlarını da yeterince dinlemediğin fark ettim.” $(O ̈, 5)$.

"Olumsuz etkisi var; çünkü kameraları pek açtırmıyorum ve ne yaptıklarına pek hâkim değilim. Katılım gösterse bile dinleme becerisi açısından uzaktan veya yakından pek bir şey değiştiğini düşünmüyorum.” $(O \ddot{O}, 6)$.

“Öğrencinin motivasyonu yüksekse dinleme becerisi de yüksek. Ev içinde uygun ortam sağlanan çocuklar hem dinleme hem de katılım açısından yüksek performans göstermektedir.” $(\ddot{O}, 7)$.

"Çevrimiçi eğitim sırasında öğrenciler, dinliyormuş gibi görünüyorlar ama dinleme becerilerine katkısı oluyor mudur bilemiyorum." $(\ddot{O}, 8)$.

"Olumsuz etkisi olduğunu düşünüyorum. Çevrimiçi eğitimde kamera açmıyorum, aktif anlatanı göremeyince çocukların dinlemede eksik kaldığını düşünüyorum. “(Ö,11).

"Dinleme becerisinin durumu hem sınıfa göre hem de yaptı̆̆ımız etkinliğe bağh olarak değişiyor." $(\ddot{O}, 18)$.

Dinleme becerisinin olumsuz etkilenmesinde öğrencilerle doğrudan göz temasının kurulamaması ve öğretmenin süreci takip edememesi ön plandadır. Evde uygun ortam sağlandığında ise dinleme becerisinin uzaktan eğitimden olumlu etkileneceği düşünülmektedir.

Dinleme becerisi, eğitim öğretim faaliyetleri uzaktan eğitimle gerçekleştiği için süreçten olumsuz etkilenmektedir. Öğretmenler, dinleme becerisinin gelişimi için göz teması kurmanın gerekliliğini vurgulamıştır. Diğer yandan dinleme becerisinin uzaktan eğitim faaliyetlerindeki gelişimi hedef kitlenin sahip olduğu bireysel özelliklere göre farklılık göstermiştir.

\section{On birinci alt probleme ilişkin bulgular}

Katılımcıların uzaktan eğitimin öğrencilerin konuşma becerileri üzerindeki etkisine dair görüşleri Tablo 12'de gösterilmiştir:

Tablo 12. Konuşma becerisine olan etki

\begin{tabular}{ll}
\hline Konuşma Becerisine Etkiye Dair Görüş & $\mathrm{N}$ \\
\hline Olumlu etkileri olduğu görülmüştür. & 5 \\
Olumsuz etkilediğini düşünüyorum. & 12 \\
Herhangi bir etkisi olmamıştır. & 4 \\
\hline
\end{tabular}

\footnotetext{
Adres | Address

RumeliDE Dil ve Edebiyat Araştırmaları Dergisi Osmanağa Mahallesi, Mürver Çiçeği Sokak, No:14/8 Kadıkoy - ISTANBUL / TÜRKIYE 34714 e-posta: editor@rumelide.com tel: +90 505 7958124, +90 2167730616

RumeliDE Journal of Language and Literature Studies Osmanağa Mahallesi, Mürver Çiçeği Sokak, No:14/8

Kadıköy - ISTANBUL / TURKEY 34714

e-mail: editor@rumelide.com,

phone: +90 $5057958124,+902167730616$
} 
Çalışmada yer alan katılımcıların 12'si salgında yürütülen uzaktan eğitimin konuşma becerisi üzerinde olumsuz etkisi olduğunu düşünmektedir. 4 öğretmen, uzaktan eğitimin konuşma becerisi üzerinde herhangi bir etkisi olmadığını; 5 öğretmen ise diğerlerinin aksine salgın sürecinde yürütülen uzaktan eğitimin konuşma becerisi üzerinde olumlu etkisi olduğunu ifade etmektedir. Yanıtlardan yapılan alıntılar aşağıda sunulmuşstur:

"Konuşma becerisi kendini iyi ifade edebilen öğrencilerde aynı şekilde devam ediyor aktif olarak katılım sağlıyorlar; ancak bazı öğrencilerin derste genelde sessiz kaldığını, düşüncelerini ifade etmediklerini görüyorum. Yüz yüze eğitim, konuşma becerisi üzerinde daha etkili oluyor tabi.” $(\ddot{O}, 5)$.

"Uzaktan eğitim öncesinde var olan durumlar devam etmektedir. Yani konuşma becerisi iyi olan öğrencilerin aynı şekilde devam ettiği, yerel ağız özellikleri ve sokak ă̆zı kullananların durumununsa neredeyse hiç değişmediğini söyleyebilirim.” (Ö,6).

"Bazı öğrencilerde olumlu etkiler olduğu görülmüştür. Sinıf ortamında psikolojik baskı yaşayan öğrenciler de gözle görülür değişiklik yaşanmıştır. Öğrencilerin dijitalde, sanalda konuşma yeteneklerinin geliştiğini ve heyecanlarm yendiklerini düşünüyorum. Hem konuşma becerileri hem de ders performansları yükselmiştir.” $(\ddot{O}, 7)$.

"Konuşma becerisi üzerinde olumsuz etkileri olduğunu düşünüyorum, çünkü yüz yüze eğitimde olduğu gibi öğrenci aktif olmuyor. Çoğu öğrenci derse katılp bilgisayar başında bile olmuyor." $(\ddot{O}, 8)$.

Çalışmaya katkı sağlayan öğretmenlerden konuşma becerisinin uzaktan eğitimden olumsuz etkilendiğini düşünenlerin gerekçesi öğrencilerin derse katılmaması ve katılsa bile ders sırasında yüz yüze eğitim kadar aktif olamamasıdır. Sürecin konuşma becerisini olumlu etkilediğini düşünen katılımcıların gerekçesi ise dijital ortamda kendini daha iyi ifade eden öğrencilerin varlığıdır.

Uzaktan eğitimde öğrencilerin derse katılmamaları konuşma becerisinin gelişimindeki en büyük engel durumundadır. Diğer yandan dijital ortamın öğrencilere özgüven kazandırdığı ve akran baskısını daha az hissedilmesine bağlı olarak konuşma becerisini desteklediği düşünülmektedir.

\section{On ikinci alt probleme ilişkin bulgular}

Uzaktan eğitimin öğrencilerin okuma becerileri üzerindeki etkisine dair katılımcı görüşleri Tablo 13’te gösterilmiştir:

Tablo 13. Okuma becerisine olan etki

\begin{tabular}{ll}
\hline Okuma Becerisine Etkiye Dair Görüş̧ & N \\
\hline Olumlu etkileri olduğu görülmüsşür. & 2 \\
Olumsuz etkilediğini düşünüyorum. & 16 \\
Herhangi bir etkisi olmamıştır. & 2 \\
Farkllık göstermekte & 1 \\
\hline
\end{tabular}

Katılımcıların 16'sı salgın sürecinde yürütülen uzaktan eğitimin okuma becerisi üzerinde olumsuz etkisi olduğunu belirtirken 2 öğretmen, uzaktan eğitimin okuma becerisi üzerinde herhangi bir etkisi olmadığını; 2 öğretmen ise diğerlerinin aksine salgın sürecinde yürütülen uzaktan eğitimin okuma becerisi üzerinde olumlu etkisi olduğunu ifade etmektedir. 1 öğretmen de durumun öğrenciden öğrenciye farklılık gösterdiğini düşünmektedir. Yanıtlardan yapılan alıntılar aşă̆ıda sunulmuştur:

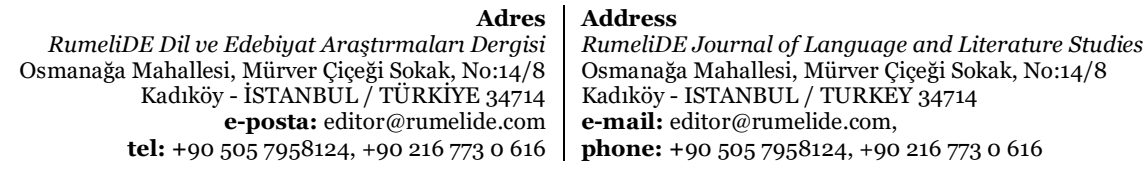


Turkish education in distance education process during the epidemic period (COVID-19) according to the views of teachers / K. Kaplan; B. Gülden (pp. 233-258)

"Salgında ekran okumalarını arttı̆̆ını, bazı sınıf seviyeleri özelinde okuma becerisine yönelik durumunun olumlu yönde değiştiğini gözlemliyorum; çünkü e-kitapla okuma becerilerini daha da geliştirebiliyorlar.” $(0,9)$.

"Yüz yüze eğitim strasında bile özellikle 8. sınıflar yani sınava hazırlanan öğrenciler, okumayı ikinci plana atmakta ki çevrimiçi eğitimde okumayı ihmal daha da arttı.” (Ö,5).

"Ders süresince okuma becerisi çalş̧malarmı gerçekleştirmek zor oluyor. Süreyi etkili kullanmak için zaman zaman okuma çalsşmalarını sınırlandırabiliyoruz. Bu nedenle salgının okuma üzerinde olumlu etkisi olduğunu söylemek oldukça güç.” $(O ̈, 6)$.

"Ders süresinin otuz dakika ile sınırlandırılması nedeniyle okumaya yönelik çalışmalara yeterli zaman ayrlamamaktadır. Okuma daha da yavaşladı.” (̋̈,17).

Ders sürelerinin kısıtlı olması ve öğrencilerin sınav kaygısı içinde olması sebebiyle katılımcılar, okuma becerisi kapsamında yürütülen etkinliklerin uzaktan eğitimden olumsuz etkilendiğini düşünmektedir. Okuma becerisinin süreçten olumlu etkilendiğini düşünen az sayıdaki katılımcı ise e-kitabın önemli bir faktör olduğunu belirtmektedir.

Okuma becerisinin salgından olumsuz etkilendiğini düşünen öğretmenlerin ortak noktasında ders saatlerinin yetersizliği; olumlu etkilendiğini düşünen katılımclların hareket noktasında ise uzaktan eğitimle artan ekran okuma ve elektronik materyal çeşitliliği bulunmaktadır.

\section{On üçüncü alt probleme ilişkin bulgular}

Uzaktan eğitimin öğrencilerin yazma becerileri üzerindeki etkisine dair katılımcı görüşleri Tablo 14’te gösterilmiştir:

Tablo 14. Yazma becerisine olan etki

\begin{tabular}{ll}
\hline Yazma Becerisine Etkiye Dair Görüş & $\mathrm{N}$ \\
\hline Olumsuz etkilediğini düşünüyorum. & 18 \\
Az da olsa olumsuz etkilediğini düşünüyorum. & 1 \\
Emin değilim. & 2 \\
\hline
\end{tabular}

Çalışma grubundaki öğretmenlerin 18’i yazma becerisinin salgın sürecinden olumsuz etkilendiğini düşünürken 1 öğretmen sürecin kısmen olumsuz etkilendiğini belirtmiştir. 2 öğretmen ise uzaktan eğitimin yazma becerisi faaliyetleri üzerindeki etkisi hakkında kararsız kalmışlardır. Verilen yanıtlardan yapılan alıntılar aşağıda sunulmuştur:

"Yazma becerisin öğretmenin verdiği yazı ödevleri dışında neredeyse hiç kullanılmadı̆̆ını düşünüyorum. Gelen ödevler yazını estetiğini geliştirecek, düzeltecek kadar kalem kullanılmadığımı, yazıya vakit ayrılmadığını açıkça göstermektedir. Özellikle alt sımıflarda satır üzerine düzgünce yazma, harflerin benzer boyutta olması, sayfa kullanımı gibi konularda eksiklikler bulunmaktadır. Üst sinıflarda günlük, şïr, sözcük defteri tutma eylemi az da olsa devam etmektedir.” $(\ddot{O}, 1)$.

"Online eğitimde yazma yerini fotokopiye ve ekran görüntüsü almaya brraktı̆̆ için çevrimiçi eğitimin yazmaya olumsuz bir etkisi olabilir, diye düşünüyorum.” (Ö,3).

“Olumsuz etkilediğini düşünmüyorum. Öyle ki ekran görüntüsü alp deftere yazmayan öğrenci çok fazla. Yüz yüze de daha fazla yazdıklarım düşünüyorum. Şu anda kimin yazı yazmadığın bile bilmiyorum." $(\ddot{O}, 5)$.

"Yazma konusu da sorun özellikle 5. smıflarda. Yazma etkinlikleri üzerinde olumsuz etki oluşturduğunu düşünüyorum.”(Ö,13).

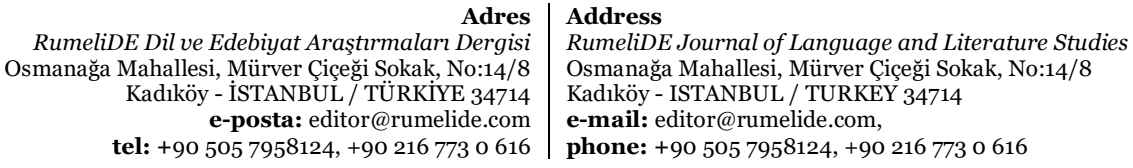

RumeliDE Dil ve Edebiyat Araştırmaları Dergisi adlö̈ tel: +90 $5057958124,+902167730616$

phone: +90 505 7958124, +90 2167730616 
"Yazma etkinliklerini sınıf içi derslerinde olduğu gibi derste yapamazsak da öncesinde görev verip sonradan paylaşabiliyorlar yazdıkların. Kısmen etkilendi denebilir.” (Ö,2).

Öğretmenlerin büyük çoğunluğu, yazma becerisinin salgın sürecinden olumsuz etkilenmesinde yazma becerisine yönelik faaliyetlerin öğrenci tarafından yapılıp yapılmadığının sağlıklı bir şekilde kontrol edilememesine bağlamaktadır. Öğrencilerin not almaması ya da yazma becerisine dönük etkinliklerden uzak durması da öğretmenlerce ifade edilmiştir. Diğer bir nokta ise dijitalleşmenin getirdiği kolaylık sebebiyle öğrencilerin yazmak yerine fotoğraf çekerek not almayı tercih etmeleridir.

Yazma becerisinin salgın sürecinden olumsuz etkilenmesinde denetimsizlik ya da dönüt alamama durumu öne çıkmaktadır. Bu durum yüz yüze eğitimle kıyaslandığında yazma faaliyetinin ödev olarak evde yapılması halinde de denetleme sorununun ortaya çıkabileceği söylenebilir. Buna karşın uzaktan eğitimde ders anında öğrencilerin yazma sürecini yürütmeleri halinde denetime ya da dönüt almaya dair yüz yüze eğitime göre belirgin bir farklılık kalmayacağı söylenebilir. Hatta uzaktan eğitim ortamı, akran değerlendirme için daha elverişli bir altyapı sunmaktadır. Örneğin ders anında öğrencilerin yazılı ürünlerinin ekran paylaşımıyla her öğrencinin rahatlıkla incelemesi mümkün olabilmektedir. Yüz yüze eğitimde öğrencinin defter veya kitap üzerine kaleme aldığı bir ürünü sınıf arkadaşlarına aynı anda sunabilmesi söz konusu olmayacaktır.

\section{On dördüncü alt probleme ilişkin bulgular}

Katılımcıların uzaktan eğitimin öğrencilerin dört temel dil becerileri üzerindeki etkisine dair görüşleri Tablo 15’te gösterilmiştir:

Tablo 15. Dört temel dil becerilerine olan etki

\begin{tabular}{ll}
\hline Dört Temel Dil Becerisine Etkiye Dair Görüş & N \\
\hline Fikrim yok. & 1 \\
Herhangi bir şey yapılamaz. & 3 \\
Ödevlendirme yapılabilir. & 1 \\
Ders saati artırılabilir. & 2 \\
Kazanım sayısı azaltılabilir. & 2 \\
Ders sırasında daha fazla söz hakkı verilebilir. & 1 \\
Öğrenci sayısı azaltılarak ve kamera açlarak işlenebilir & 4 \\
Öğrenciyi daha aktif kılacak oyun içerikli uygulama ve etkinlikler geliştirilmeli & 5 \\
Aile sürece dâhil edilmeli. & 2 \\
\hline
\end{tabular}

Katılımcıların soruya verdiği cevaplara bakıldığında uzaktan eğitim döneminde dört temel dil becerisindeki olumsuz etkiyi ortadan kaldırmak için 5 öğretmen, öğrenciyi aktif kllacak etkinliklere yer vermek gerektiğini belirtmekte; 4 öğretmen, öğrenci sayısının azaltılarak kamera açmanın zorunlu hale getirilmesini istemektedir. 3 öğretmen ise yaşanan bu sorunun çözümsüz olduğunu iddia etmektedir. Ders saatlerinin ve kazanım saylarının artırılmasını, ailelerin sürece dâhil edilmesini isteyen ikişer öğretmen bulunmaktadır. Öğrencilere daha fazla söz hakkı verilebileceğini ya da ilave ödev verilebileceğini dile getiren birer öğretmen vardır. Verilen yanıtlardan yapılan alıntılar aşağıda sunulmuştur:

"Okumanın gerekliliği fark ettirilmeli; okumaktan zevk aldıracak eserler tavsiye edilmelidir. Zamanın ruhuna uygun düşecek blog, web sitesi, sosyal medya içerikli okumalar da okuma

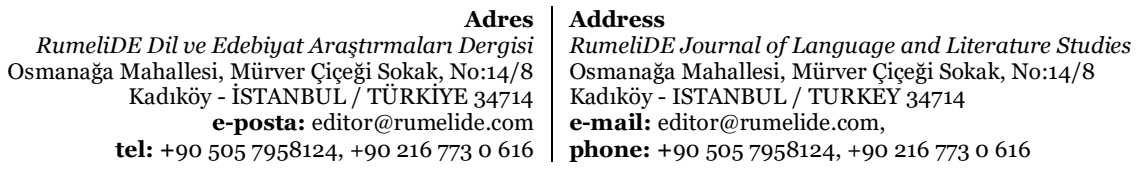


Turkish education in distance education process during the epidemic period (COVID-19) according to the views of teachers / K. Kaplan; B. Gülden (pp. 233-258)

\begin{abstract}
listelerine dâhil edilmelidir. Türk edebiyatının önemli isimleri öğrenci seviyesine uygun biçimde tavsiye edilmeli, herkes illa bunu okumal diye diretilmemelidir. Cizgi romanlar, karikatür okumaları, illüstrasyonlar, grafitiler vb. sanatın birkaç kolunu birleştiren ürünlere de yer verilmelidir. Sanal izlemeler yapılabilecek, katılım sağlanabilecek kültür portalları konusunda öğrenciler bilgilendirilmeli, ekran karşısında da kaliteli, öğretici, zevkli zaman geçirilebileceği fark ettirilmelidir. Yazma becerisinin geliştirilmesi için çeşitli türlerde ödevler verilmeli, bu ödevler ifade gücünü geliştirecek, yazmaya cesaretlendirecek biçimde mutlaka değerlendirilmeli ve öğrenciye dönüt verilmelidir. Şïr, şarkı, türkü, rap, edebiyattan uyarlanan filmlerle öğrenciler karşılaştırılmalı; bu vesileyle doğru okumanın, dinlemenin nasıl yapılacağı hissettirilmeli, edebi eserlere dikkat çekilmelidir. Resim okumaları, şür yorumlama, bir eser üzerine düşünme konuşma gibi etkinliklere yer verilmelidir.” $(\ddot{O}, 1)$.
\end{abstract}

"Dört temel dil becerisi üzerine etkinlikler planlanmalı. Hazırlıkl ve hazırlıksız konuşma, okunan kitaplar ile ilgili etkinlikler, değerlendirmeler yapılmalı. Ayrıca herhangi bir konuda yazı yazma ve yazdiğını arkadaşlarıyla paylaşma etkinlikleri yapılmalı.”(Ö,2).

"Müfredat sınırlandırılırsa bu beceriler üzerine daha fazla çalışma olanağı elde edilmiş olur. Konular ancak yetişiyor. Yazma, okuma, dinleme becerileri için etkinlik yapmaya zaman olmuyor." $(\ddot{O}, 3)$.

"Özellikle yazma becerileri alanında çalışmalar aksatılmamahdır. Ayrıca ders kitabının zkitaplara göre önceliğinin olması gerektiğini düşünüyorum.” $(\ddot{O}, 4)$.

“Öğrencilerin derse katılımı tam sağlanmalı, öğretmen ile iş birliği içinde verilen ödev, görev ve çalışmalar velilerce takip edilmelidir.” $(\ddot{O}, 5)$.

“Online eğitimde devam zorunluluğu ve kamera açma zorunluluğu getirilirse bazı kayıplar kazanca dönüşebilir.” (Ö,8).

“Öğrenciyi daha aktif kılacak ve oyun içerikli uygulamalar geliştirilmeli.” (Ö,12).

“Kazanımlarn azaltılması gerekir.” $(O ̈, 16)$.

Uzaktan eğitimin dört dil becerisi üzerindeki olumsuz etkiyi ortadan kaldırma noktasında müfredatta yer alan konuların sınırlandırılması, Türkçe ders saatinin artırılması ve eğitim- öğretim faaliyetleri sırasında öğrencileri daha aktif kılacak seviyelerine uygun farklı etkinlikler hazırlanması, uzaktan eğitime uygun materyaller geliştirilmesi ön plandadır. Başka bir husus da uzaktan eğitimde devam zorunluluğu olmasının gerekliliğidir.

Yaşanan olumsuzluğun ortadan kaldırılabilmesinde çıkış yolu olarak ders saatinde artış yapılması ve müfredata sınırlama getirilmesi görülmektedir. Ayrıca etkili bir dil becerisi gelişimi için zenginleştirilmiş ortamlar ve hedef kitleye uygun farklı materyaller de önemlidir. Dikkat çeken bir başka durum da uzaktan eğitim sonrasında temel dil becerilerinde yaşanan sorunların giderilemeyeceğini düşünen öğretmenlerin varlığıdır. Bu durum hem öğrenciler hem ana dili eğitimi hem de Türk eğitim sistemi için oldukça kaygı verici bir durumdur.

\title{
On beşinci alt probleme ilişkin bulgular
}

Uzaktan eğitimin dil bilgisi konularının öğretimi üzerindeki etkisine dair katılımcı görüşleri Tablo 16'da gösterilmiştir:

Tablo 16. Dil Bilgisi Konularının Öğretimine Etki

\begin{tabular}{ll}
\hline Dil Bilgisi Konularının Öğretimine Etkiye Dair Görüşs & N \\
\hline Olumlu etkileri olduğu görülmüştür. & 10 \\
Olumsuz etkilediğini düşünüyorum. & 6 \\
Herhangi bir etkisi olmamıştır & 4 \\
Fikrim yok. & 1 \\
\hline
\end{tabular}

Adres

RumeliDE Dil ve Edebiyat Araştırmaları Dergisi Osmanağa Mahallesi, Mürver Çiçeği Sokak, No:14/8 Kadıköy - İSTANBUL / TÜRKIYE 34714 e-posta: editor@rumelide.com tel: +90 $5057958124,+902167730616$
Address

RumeliDE Journal of Language and Literature Studies

Osmanağa Mahallesi, Mürver Çiçeği Sokak, No:14/8

Kadıköy - ISTANBUL / TURKEY 34714

e-mail: editor@rumelide.com,

phone: +90 $5057958124,+902167730616$ 
Çalışmaya katılan öğretmenlerin 10’u dil bilgisi konularının öğretimine uzaktan eğitimin olumlu etkileri olduğunu belirtirken 6'sı uzaktan eğitimin olumsuz etkilerini dile getirmiştir. 4 öğretmen, olumlu ya da olumsuz herhangi bir etkinin söz konusu olmadığını ifade etmiş; bir öğretmen ise fikir beyan etmek istememiştir. Verilen yanıtlardan yapılan alıntılar aşağıda sunulmuştur:

"Dil bilgisi konularınm öğreniminde herhangi bir sorun yaşanmamıştır. Yapılan sinavlar ve etkinlikler göstermektedir ki dil bilgisi ile ilgili kazanımlar, büyük ölçüde kazandırılmıştır.” (Ö, 11).

"Yüz yüze eğitime göre daha olumlu bir etkisinin olduğunu düşünüyorum; çünkü derslerde materyal çeşitliliği ve kullanım kolaylı̆̆ sağ lıyor.” (Ö, 12).

"Çevrimiçi eğitimin daha olumlu bir etkisinin olduğunu düşünüyorum, materyal çeşitliliği ve kullanım kolayh̆̆̆ itibarıla.” $(\ddot{O}, 10)$.

"Dil bilgisi etkinliklerinde herhangi bir sorun olmuyor, genel olarak olumlu dönüt alabiliyorum." $(\ddot{O}, 16)$.

“Öğretmen olarak iyi etkinlik plânlamışsak daha etkili oluyor, herhangi bir sorun olmuyor.” (Ö, 17).

“Olumsuz etkisi var bana göre. Dersteki gibi öğrenme olmuyor, dil bilgisi konularını öğretiminde.” $(\ddot{O}, 14)$.

"Olumsuz etkisi var. Bazen ders surasında anlattıklarımızı çizmek, onların üzerinde göstermek imkânsız oluyor. Teknolojik aletlerin azizliğine uğrayabiliyoruz.” $(\ddot{O}, 13)$.

Özellikle materyal çeşitliliği sağladığı için uzaktan eğitimin dil bilgisi konularının öğretimine olumlu katkı sağladığı anlaşılmaktadır. Uzaktan eğitimin dil bilgisi konularının öğretimine olumsuz etkisinde ise uzaktan eğitim araçlarının kullanımındaki yetersizlik öne çıkmaktadır.

Uzaktan eğitimin dil bilgisi konularının öğretimine büyük ölçüde olumsuz bir etkisinin olmadığı anlaşılmaktadır. İyi bir planlama yapıldığında ve uzaktan eğitim araçlarının kullanımına dair bilgi sahibi olunduğunda sorun olmamaktadır.

\section{On altıncı alt probleme ilişkin bulgular}

Uzaktan eğitimin öğrencilerin Türkçe dersine olan tutumları üzerindeki etkisine dair katılımcı görüşleri Tablo 17'de gösterilmiştir:

Tablo 17. Türkçe dersine olan tutuma etkisi

\begin{tabular}{ll}
\hline Türkçe Dersine Olan Tutuma Etkiye Dair Görüş & N \\
\hline Olumlu etkileri olduğu görülmüştür. & 2 \\
Olumsuz etkilediğini düşünüyorum. & 13 \\
Herhangi bir etkisi olmamıştır & 3 \\
Öğrenciden öğrenciye değişiklik göstermekte & 2 \\
Fikrim yok & 1 \\
\hline
\end{tabular}

Katılımcıların 13’ü uzaktan eğitimle yürütülen derslerin öğrencilerin Türkçe dersine olan mevcut tutumunu olumsuz etkilediğini düşünmektedir. 3'ü ise öğrencilerin Türkçe dersine olan mevcut tutumunda herhangi bir değişiklik olduğunu düşünmezken 2 öğretmen, tutum değişikliğinin öğrenciden öğrenciye farklllık gösterdiğini dile getirmiştir. 2 öğretmen de çevrimiçi derslerin öğrencilerin Türkçe dersine olan mevcut tutumunu olumlu yönde etkilediğini belirtmiştir. Bir öğretmen ise fikir beyan etmemiştir. Verilen yanıtlardan yapılan alıntılar aşağıda sunulmuştur:

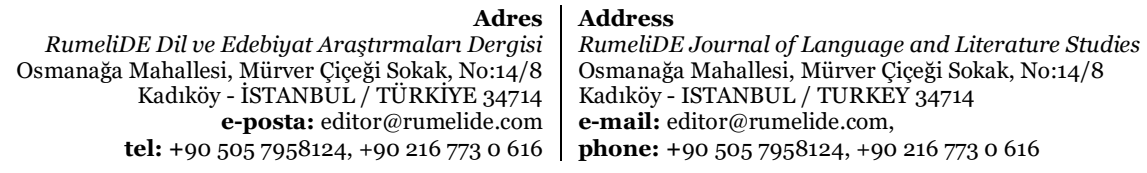


Turkish education in distance education process during the epidemic period (COVID-19) according to the views of teachers / K. Kaplan; B. Gülden (pp. 233-258)

"Çocuklar, her zaman yüz yüze derste daha mutlu olurlar. O yüzden şu an çok da olumlu tutumları yok. Hem okula karşı hem de Türkçe derslerine karşı olumsuz tutum gelişti.” (Ö, 6).

"Olumsuz tutum oluşturuyor çevrimiçi öğrenme. Okuma, yazma etkinlikleri verimli olmadiğı için öğrenci soğuyor, Türkçe derslerinden.” $(\ddot{O}, 7)$.

"Okuma konuşma ve yazma alanlarında giderek isteksizleşiyorlar. Bu da derse karşı olumsuz tutuma neden oluyor." (Ö, 9).

“Türkçe olarak değil de genel manada eğitim öğretim faaliyetlerine karşı olumsuz tutum oluştu.” $(\ddot{O}, 13)$.

“Öğrencilerin tutumlarında genellikle olumlu yönde değişiklik olduğunu düşünüyorum. 6. sınıflarla yüz yüze tanışmamış olmama rağmen derse katılımları da çok iyi bana hissettirdikleri de sevgileri de çok iyi.” (Ö, 4).

“Öğrenciden öğrenciye değişiklik gösterebiliyor; ancak genel itibartyla yüz yüze eğitimde derse ilgisi olan öğrencilerin aynı şekilde istekli ve ilgili olduğunu söyleyebilirim.” $(\ddot{O}, 5)$.

"Bu süreçte öğrencilerin derse olan tutumlarmın öğrenciye göre değiştiğini, farkhlık gösterdiğini düşünüyorum.” $(O ̈, 14)$.

Öğretmenlerin uzaktan eğitimin öğrencilerin Türkçe dersine olan tutumlarını olumsuz etkilediğini düşünmelerinde temel dil becerilerinden okuma, konuşma ve yazma becerisine yönelik etkinliklerin verimsizliği ön plana çıkmaktadır. Katılımcıların diğer cevapları incelendiğinde öne çıkan bir diğer husus da derse olan tutumun sınıftan sınıfa hatta öğrenciden öğrenciye değiştiği gerçeğidir.

Sadece Türkçe dersi özelinde değil, genel manada eğitim öğretim faaliyetlerine karşı öğrencilerde olumsuz bir tutum geliştiği anlaşılmaktadır. Diğer bir tespit de salgın döneminde Türkçe dersine karşı tutumun bireysel farklılıklar gösterdiğidir.

\section{On yedinci alt probleme ilişkin bulgular}

Katılımcıların uzaktan eğitimin iş yüklerini artırıp artırmadığına dair görüşleri Tablo 18'de gösterilmiştir:

Tablo 18. İş yüküne etkisi

\begin{tabular}{ll}
\hline İş Yüküne Etkiye Dair Görüsş & $\mathrm{N}$ \\
\hline Evet & 12 \\
Hayır & 8 \\
Kısmen & 1 \\
\hline
\end{tabular}

Çalışma grubunda yer alan katılımcılardan 12'si yüz yüze eğitim ile kıyaslandığında iş yükü noktasında uzaktan eğitimin yüklerini artırdığını düşünürken 8’i ise iş yükünde herhangi bir değişiklik olmadığını belirtmiştir. Öğretmenlerden biri ise çevrimiçi eğitimin yüklerini kısmen artırdığını ifade etmiştir. Sorulara verilen yanıtlardan yapılan alıntılar aşağıda sunulmuştur:

“Işs yükünden ziyade sürecin oldukça yıpratıcı olduğunu düşünüyorum.” (Ö,18).

"Yüz yüze derslere göre çevrimiçi derslerde ders programımız saat olarak günümün geniş bir alanına dağıldr.” (Ö,9).

“Kesinlikle iş yükümüzün arttı̆̆ın düşünüyorum.” $(O ̈, 10)$

"Hayır. Yüz yüze eğitimde nasıl ders öncesi, esnası, sonrasmı düşünerek plan ve program yapıyorsak şimdi de benzer bir şekilde devam ediyoruz. Öğrencilerle iletişim doğru kurulduğunda yük arttı̆̆ın düşündürecek bir durum da yaşanmıyor.” (Ö,2O).

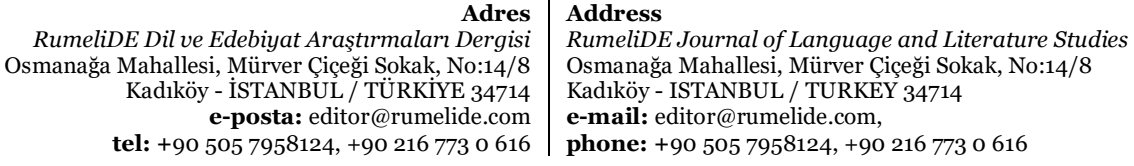


"Sadece zaman konusunda çevrimiçi derslerin uygun olmadığını düşünüyorum. Çünkü çocuklar için sabah kahvaltısı ve öğle yemeği düşünülmemiş; ama biz zaten okulda da aynı derslere girecektik. Çok fazla iş yükü ortaya çıkardığımı düşünmüyorum.” $(O ̈, 14)$.

Çalışma grubundaki öğretmenlerden uzaktan eğitimin iş yükünü artırdığını düşünenler daha çok ders saatlerinin uygun olmamasını gerekçe gösterirken uzaktan eğitimin iş yükünü artırmadığını düşünenler ise gerekçe olarak yüz yüze eğitimdeki hazırlık ve planlamanın uzaktan eğitimde de devam ettiğini göstermektedir.

Uzaktan eğitimin iş yükünü artırıp artırmadığı konusunda öğretmenlerin iki görüşe ayrıldığını söylemek mümkündür. İş yükünün artmasında uzaktan eğitimle sürdürülen derslerin programdaki saati belirleyici unsur olarak görünmektedir. Bir yandan da yoklama alınması, ders defterinin ders anında doldurulması gibi zaman alıcı durumların uzaktan eğitimde söz konusu olmaması çevrimiçi öğrenme ortamlarının iş yükünü azaltıcı yönleri olarak ön plana çıktığı söylenebilir. Aynı zamanda yüz yüze eğitimde fiziksel ortamı eğitime hazır hale getirmek (tahtayı silmek, ders dışı uyarıcılardan etkilenmek...), ulaşıma zaman ve bütçe ayırmak gibi faktörlerin olmaması, uzaktan eğitimin iş yükünü azaltıcı yönleri olarak ifade edilebilir.

\section{On sekizinci alt probleme ilişkin bulgular}

Uzaktan eğitimin eğitim sisteminin bir parçası olup olmamasına dair katılımcı görüşleri Tablo 19'da gösterilmiştir:

Tablo 19. Uzaktan Ĕ̆itimin Eğitim Sisteminde Devamlllı̆̆

\begin{tabular}{lc}
\hline Uzaktan Eğitimin Eğitim Sisteminin Devamına Dair Görüş & $\mathrm{N}$ \\
\hline Evet & 11 \\
Hayır & 6 \\
Olabilir & 4 \\
\hline
\end{tabular}

Salgın koşullarının ortadan kalmasından sonra da uzaktan eğitimin devamına dair verilerin yer aldığı tablo incelendiğinde çalışma grubundaki öğretmenlerin 11’i salgın sonrasında da uzatan eğitimin eğitim sisteminde yer almasını istemiş, 4’ü ise "olabilir." cevabını vererek olumlu görüş bildirmiştir. Öğretmenlerden 6'sı ise salgın sonrası uzaktan eğitimin devamını istememektedir. Çalışma grubunda yer alan öğretmenlerin yanıtlarına dair alıntılar aşă̆ıda sunulmuştur:

"Evet, zamane öğrencilerinin hayatında dijital içerik ve teknolojik araçlarm yerinin ne denli önemli olduğu aşikârken bu tür sistemleri kullanmanın yararlı olacağı kanaatindeyim.”(Ö,9).

“Olumlu yönleri var elbette. Özellikle eğitim araçlarını doğru kullanan ve araçlardan yararlanmak isteyen öğrenciler için çeşitlilik daha fazla.” $(\ddot{O}, 14)$.

"Normal şartlarda eğitimin yüz yüze olması taraftarııı. Çünkü sınıf tam olarak katılmadığı için herkes aynı eğitimden yararlanamıor. Herkesin İnterneti, bilgisayarı yok.” $(\ddot{O}, 18)$.

"Öğrencilere hayır. Onlarla yüz yüze eğitim yapmak istiyorum ama velilerle çevrimiçi eğitim olabilir.” $(\ddot{O}, 20)$.

Çalışma grubunda yer alan öğretmenler, teknolojinin öğrencilerin yaşantısındaki yerini dikkate almakta ve bu sebeple normal eğitim sürecinde de uzaktan eğitimin devamını istemektedir. Bir başka gerekçe olarak da uzaktan eğitimin eğitim- öğretim faaliyetlerine kattığı çeşitlilik gösterilmiştir. Normal eğitim

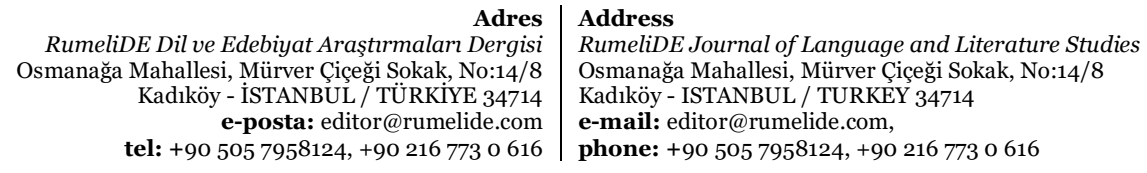


sürecinde uzaktan eğitimin devamını istemeyen katılımcılar ise gerekçe olarak "fırsat eşitsizliği"ni göstermektedir.

Katılımcıların cevapları değerlendirildiğinde öğretmenler, teknolojik gelişmeleri de dikkate alarak uzaktan eğitimin eğitim sistemine olumlu katkı sağlayacağını düşünmekte; ancak tüm öğrencilerin aynı imkâna sahip olmaması nedeniyle de kaygılanmaktadır.

\section{On dokuzuncu alt probleme ilişkin bulgular}

Katılımcıların uzaktan eğitimin LGS başarısı üzerindeki etkisine dair görüşleri Tablo 20'de gösterilmiştir:

Tablo 2o. LGS Başarısına Etkisi

\begin{tabular}{lc}
\hline LGS Başarısına Etkiye Dair Görüş & $\mathrm{N}$ \\
\hline Olumlu & - \\
Olumsuz & 16 \\
Herhangi bir etkisi olmaz & 5 \\
\hline
\end{tabular}

Tablo incelendiğinde çalışma grubunda yer alan öğretmenlerden 16'sı salgın nedeniyle ortaya çıkan uzaktan eğitimin öğrencilerin LGS'deki Türkçe başarısını olumsuz etkileyeceğini düşünmektedir. Katılımcılardan 5’i ise uzaktan eğitimin LGS'deki Türkçe başarısına herhangi bir etkisinin olmayacağını düşünmektedir. Çalışma grubunda yer alan öğretmenlerin sorulara verdiği yanıtlardan alıntılar yapılarak aşağıda sunulmuştur:

"Öğrencilerimden birçoğunun çahşmayı bıraktı̆̆ını seziyorum. Olumsuz etkisi olduğunu düşünüyorum.” $(O ̈, 8)$.

"Başarı düşecektir. Şu anda ölçme değerlendirme çalışmaları ekran üzerinden yapılmakta, bu da sonucu, okumayı, dikkat süresini olumsuz etkilemekte.” (Ö,9).

"Her öğrencinin İnternet erişiminin ayn olmamaktadır. Bu nedenle yüz yüze eğitimin dersin takibi açısından daha etkili olacağını düşünüyorum." $(0 \ddot{O}, 15)$.

"Olumsuz etkileyeceğini düşünmüyorum. Çünkü sinava hazırlanan ve amacı olan öğrenciler, çalışmalarıı aynı ciddiyetle devam ettirmektedir.” (Ö,21).

“Çok etkilemez. Çünkü bütün öğrencilerimiz aynı koşullarda eğitim görüyor.” $(O ̈, 14)$.

“Çokfazla etkileyeceğini düşünmüyorum; çünkü yüz yüze de eğitim aldılar.” (Ö,11).

Katılımcıların cevaplarına bakıldığında öğrencilerin LGS başarısı anlamında süreçten olumsuz etkileneceğini düşünen öğretmenler, gerekçe olarak her öğrencinin İnternet erişiminin olmamasına, öğrencilerin çoğunun çalışmayı bırakmasına, okuma becerilerindeki ve dikkat sürelerindeki gerilemeye bağladığı anlaşılmaktadır. Öğrencilerin olumlu ya da olumsuz herhangi bir şekilde etkilenmeyeceğini düşünen katılımcılar ise gerekçe olarak tüm öğrencilerin aynı süreçten geçmesini, az da olsa 2020-2021 eğitim- öğretim yılında öğrencilerin belirli bir süre yüz yüze eğitim almalarını göstermektedir. Öne çıkan cevaplardan biri de sürecin başından itibaren hedefi doğrultusunda çalışmalarını sürdüren öğrencilerin herhangi bir olumsuzluktan etkilenmeden çalışmalarını sürdürdükleridir.

Öğretmenlerin büyük çoğunluğu LGS'deki Türkçe başarısının uzaktan eğitimden olumsuz etkileyeceğini düşünmektedir.

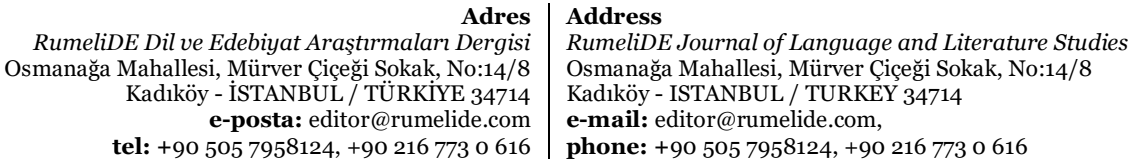




\section{Tartışma ve sonuç}

Küresel bir salgına dönüşen koronavirüs, dünyada varlı̆̆ı 180o'lü yıllara; ülkemizde ise ilk denemeleri 1900'lü yılların ortalarına dayanan uzaktan eğitimin yerel ya da uluslararası ölçekte yaşanması muhtemel deprem, savaş, salgın gibi olağanüstü durumlarda eğitim- öğretim faaliyetlerinin sürdürülmesinde etkili olacağını ortaya koymuştur. Ülkemiz de koronavirüs sürecinde yükseköğretim kurumlarında uzaktan eğitim merkezleri ile temel eğitim ve ortaöğretimde ise Ĕ̆itim Bilişim A $\breve{g}$ üzerinden akademik faaliyetler yürütülmüştür. Alınan tedbirlerle akademik süreç devam ettirilmesine rağmen uzak eğitim faaliyetleri sırasında birtakım sorunlar ortaya çıkmıştır.

Araştırma kapsamında katılımcıların büyük çoğunluğunun günlük ortalama 4-7 saat arası uzaktan eğitim ile Türkçe dersi verdiği anlaşılmakta ancak çalışmaya katılan öğretmenlerin sadece 2'sinin daha önce uzaktan ders anlatma tecrübesine sahip olduğu görülmüştür. Bu bulgular, öğretmenlerin uzaktan eğitime bilgi, beceri ve donanım anlamında hazırlıksız yakalandığını açıkça ortaya koymuştur. Hiltz \& Shea (2005), çalışmasında daha önce uzaktan eğitimi tecrübe etmeyen öğreticilerin kendilerini acemi olarak nitelediklerini ve bu durumun öğreticiyi etkilediğini ortaya koymaktadır. Alakoç (2001) da öğretim elemanlarıyla yürüttüğü çalışmasının sonuç bölümünde öğretim elemanlarının çoğunun uzaktan eğitim konusunda yeterince bilgi ve tecrübesinin olmadığını, bunun da çevrimiçi eğitim vermeye yönelik motivasyonlarını olumsuz etkilediğini belirtmektedir. Yapılan çalışmalarda eğitimdeki paydaşların uzaktan eğitime hızlı geçiş konusunda hazır olmadığı sonucuna varmıştır (Özdoğan \& Berkant, 2020; Özyürek, Begde, Yavuz, \& Özkan, 2016). Alanyazındaki sonuçlar, araştırmamızı bu yönden destekler niteliktedir. Her ne kadar öğretmenler, deneme yanılma yöntemiyle reaksiyon göstererek salgın sürecinde uzaktan eğitime katkı vermek istese de başlangıçta beklenen verimlilik sağlanamamıştır.

Yine araştırma sonuçlarından Millî Eğitim Bakanlığının çevrimiçi eğitimi EBA ve Zoom üzerinden sürdürmesinin etkisiyle çevrimiçi eğitimde öğretmenlerin daha çok EBA, Zoom ve WhatsApp'tan yararlandığı anlaşılmıştır.

Katılımcı görüşlerinden elde edilen verilere göre uzaktan eğitimdeki sorunlar genelde iki noktada toplanmaktadır: Öğrencilerin tamamının uzaktan eğitime katıl(a)maması, uzaktan eğitime katılan öğrencilerin derse katılımlarının yetersizliği. Teknolojik altyapının yetersizliği, uzaktan eğitim araçlarının eksikliği, öğrencilerin sosyoekonomik durumlarındaki farklılıklar öğrencilerin derslere katılımının önündeki önemli engeller olarak görülmektedir. Öğrencilerin uzaktan eğitim sırasında derse aktif olarak katılmak istememesinde ise özgüven eksikliği, uzaktan eğitim konusunda tecrübesizlik gibi durumlar dikkat çekmektedir. Bu sonuçlar, Erturgut (2008) ve Özdoğan \& Berkant'ın (2020) çalışması ile benzerdir. Araştırmanın diğer alt probleminden elde edilen bulgular da bunu desteklemektedir. Katılımcılar, uzaktan eğitime öğrenci katılımını yeterli bulmamaktadır. Millî Eğitim Bakanlığı tarafından uzaktan eğitimin salgın sonrasında da eğitim- öğretim faaliyetlerinin bir parçası olmaya devam edeceğinin açıklanmasından hareketle gerekli altyapının tüm ülkede sorunsuz bir şekilde işleyecek düzeye getirilmesi, acil durumlarda uygulamaya koyulabilecek dinamik bir uzaktan eğitim planının olması, öğretmen ve velilerin uzaktan eğitim konusunda gerekli bilgi ve becerilerle donatılması gerekmektedir. Öğrencinin derslere düzenli katılamaması, teknik altyapı yetersizliğini uzaktan eğitimin dezavantajı olarak gören çalışmalar ile çalışmanın sonucu tutarlıdır (Ramos-Morcillo, Leal-Costa, Moral-Garcīa, \& Ruzafa-Martīnez, 2020; Keskin ve Özer Kaya, 2020; Paepe, Zhu, \& DePryck, 2018; Koç, 2020). Kaya (2002), uzaktan eğitimin olumsuz yönlerine dair kullanılan materyallerin iyi olmaması durumunda uzaktan eğitime yönelik çabaların karşılı̆̆ını bulamayabileceğini belirtir. Söz konusu ifade

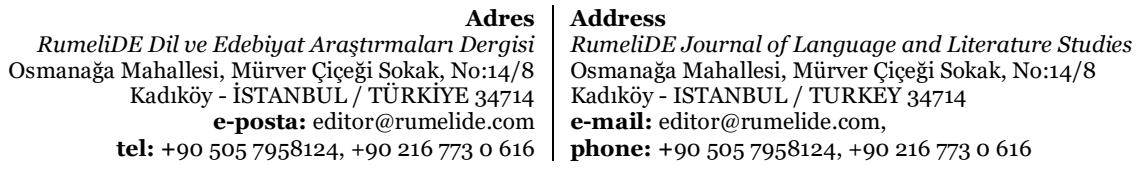


Turkish education in distance education process during the epidemic period (COVID-19) according to the views of teachers / K. Kaplan; B. Gülden (pp. 233-258)

uzaktan eğitimde materyalin etkililiğini vurgulamaktadır. Bu tespit çalışmadan elde edilen uzaktan eğitimdeki sorunlar içerisindeki materyallerin yetersizliği sonucunu desteklemektedir.

Eğitim faaliyetlerinin etkili olmasındaki unsurlardan biri de velilerdir ancak katılımcı görüşlerine göre velilerin uzaktan eğitim sürecine katkısı oldukça sınırlıdır. Bayburtlu (2020) da uzaktan eğitime veli desteğinin yetersiz olduğunu tespit etmiştir. Söz konusu sınırlı katkı, eğitim faaliyetleri ile hedeflenen amaçlara ulaşılmasını güçleştirmektedir. Eğitimin önemli paydaşlarından velilerin uzaktan eğitim konusunda bilgilendirilmemesi, velilerin süreç içerisinde acemilik yaşamasına neden olduğu gibi sürece olumlu katkı verememesine de neden olmuştur.

Katılımcıların verdiği cevaplara göre uzaktan eğitim, öğretmenlerin bireysel anlamda sosyalleşmesine engel olmaktadır, bu süreçte öğretmenler hem öğrencileri hem de diğer bireylerle dijital yollarla sosyalleşme firsatı bulmuştur. Alan yazındaki çalışmalar (Hotaman, 2020), uzaktan eğitimin öğrencilerin ve öğretmenlerin sosyalleşme ihtiyaçlarını arttırdığını göstermektedir. Aynı şekilde Attri (2012) de çalışmasında uzaktan eğitim faaliyetlerinde öğrenci ve öğretmen arasındaki iletişim ile sınıf içi etkileşimin artırılması gerektiği sonucuna varmıştır. Sonuçta eğitim öğretim faaliyetleri salt akademik bilgilerden oluşmamakta, bu süreçte öğrenciler ve öğretmenler aynı zamanda sosyalleşme fırsatı da yakalamaktadır. 30 dakika süren çevrimiçi derslerle yüz yüze eğitimdeki etkileşimin sağlanması güç görünmektedir.

Uzaktan eğitimin katılımcıların motivasyonlarına olan etkisine dair verilere göre öğretmenlerin çoğu, yüz yüze eğitimdeki meslekî hazzı almamaları sebebiyle motivasyon noktasında kayı yaşamaktadır. Çevrimiçi öğrenmenin öğretici-öğrenen etkileşiminin azalması sebebiyle motivasyonu etkilediğini belirten çalışmalar (Taşlıbeyaz, Karaman, \& Göktaş, 2014) araştırma sonuçlarıyla tutarlılık göstermektedir.

Uzaktan eğitim sırasında öğrencilerle göz teması kurulamadığı ve öğretmenler dinleme faaliyetleri sırasında öğrencileri yüz yüze eğitimdeki kadar bire bir takip edemediği için dinleme becerileri uzaktan eğitimden olumsuz etkilenmiştir. Öğrenme ortamında yapılacak düzenlemelerle olumsuzluğun giderilebileceği düşünülmektedir. Karakuş, Ucuzsatar, Karacaoğlu, Esendemir, \& Bayraktar’ın (2020) uzaktan eğitim ile ilgi çalışmasına göre öğretmen adayları uzaktan eğitimin dinleme becerisine katkı sağladığını düşünmesine rağmen dış etkenler sebebiyle dinleme becerisinin olumsuz etkilendiğini de dile getirmektedir.

Uzaktan eğitim kapsamındaki derslere öğrencilerin farklı sebeplerle katıl(a)maması, katılanların da derste yeterince aktif olmaması nedeniyle konuşma becerisi süreçten olumsuz etkilenmiştir. Bununla birlikte dijital ortamın öğrencilere özgüven kazandırdığını, bu özgüvenin de konuşma becerisini desteklediğini düşünenler de bulunmaktadır. Benzer tespit Karakuş, Ucuzsatar, Karacaoğlu, Esendemir, \& Bayraktar'ın (2020) Türkçe öğretmeni adayları için yaptığı çalışmada da tespit edilmiştir. Gewin (2020) salgın döneminde yürütülen derslerin niteliğini artırmak için öğrencinin derse katılması, ders içi aktif katılımın sağlanması ve etkileşimin artırılmasına yönelik öneriler sunmuştur. Serçemeli ve Kurnaz (2020), salgının öğrenciler üzerindeki etkisine dair yapmış olduğu çalışmada öğretmen ile öğrenci arasındaki etkileşim yetersizliğini uzaktan eğitimin dezavantajı olarak değerlendirmektedir. Birkök (2006), sanal ortamdaki grupların aynı mekânı paylaşamamaları sebebiyle grup içi etkileşimin sınırlı kaldığını belirtir ve bu sebeple grubun performansının düştüğünü vurgular. Bu vurgu ve tespitler, çalışmanın sonuçlarıyla uyumludur. Bu nedenle uzaktan eğitime dönük materyallerin hem akademik başarıyı hem de öğrencilerin sosyal, psikolojik ihtiyaçlarını desteklemesi sağlanmalıdır.

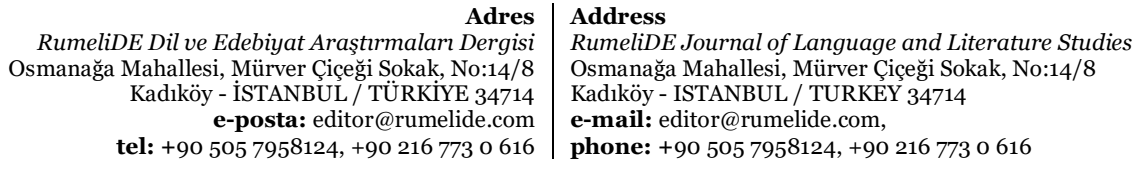


Ekran okumadaki artış sebebiyle okuma becerisi, uzaktan eğitimden olumlu etkilenmesine rağmen ders süresinin kısalığı ve müfredat yoğunluğu sebebiyle okuma becerisi uzaktan eğitimden olumsuz yönde de etkilenmiştir. Okumaya dair etkinliklerin sınırlı kaldığını ifade eden çalışmalar (Karakuş, Ucuzsatar, Karacaoğlu, Esendemir, \& Bayraktar, 2020), araştırma sonucunu destekler niteliktedir.

Uzaktan eğitim döneminde yazma becerisi, öğrencilerin yazmaya dönük faaliyetlere katılımının öğretmen tarafından kontrol edilememesi ve yazma becerisine yönelik etkinliklere karşı olumsuz tutumu nedeniyle olumsuz etkilenmiştir.

Uzaktan eğitimin dört temel becerisi üzerindeki olumsuz etkisini ortadan kaldırma noktasında çalışma grubunda yer alan öğretmenler, haftalık ders saati çizelgesinde Türkçe ders saatinin artırılmasını, müfredat kapsamının daraltılmasını, uzaktan eğitime uygun materyaller geliştirilmesini ve derse devam zorunluluğunun uzaktan eğitimde de olması gerektiğini belirtmiştir. Bu doğrultuda hâlihazırda ortaöğretim seviyesindeki dersler için sunulan z- kitapların ilköğretim için de öğretmenlerin kullanımına sunulmasının uzaktan eğitimin işlevselliğini artırmaya katkı sağlayabileceğini ve böylelikle temel beceriler üzerinde dile getirilen olumsuz etkilerin daha aza indirilebileceği tavsiye edilebilir.

Dil bilgisi konularının uzaktan eğitimden dört temel dil becerisi kadar olumsuz etkilenmediği görülmektedir. Dil bilgisine yönelik materyallerdeki eksiklik, uzaktan eğitimin önünde engel teşkil etmektedir. Bu sebeple uzaktan öğretime uygun yeni dijital içerikler üretilerek tüm öğrencilerin faydalanabileceği şekilde erişime açılmalıdır.

Covid-19 süreci sadece Türkçe dersine olan tutumu değil, aynı zaman tüm eğitim öğretim faaliyetlerine olan tutumu olumsuz yönde etkilemiştir. Dört temel dil becerilerine yönelik yürütülen faaliyetlerin verimsizliği bu durumun başlıca sebebi olarak değerlendirilmiştir. Bu sonuç, araştırmanın alt problemlerinden elde edilen sonuçların birbiri ile tutarlı olduğunu da ortaya koymaktadır.

Katılımcı öğretmenlerin bir kısmı uzaktan eğitimin ders saatlerinin düzensiz olması sebebiyle iş yükünü artırdığını düşünürken bir kısmı da uzaktan eğitime de yüz yüze eğitimdeki gibi hazırlık yaptığını belirterek iş yükünün aynı kaldığını belirtmiştir.

Uzaktan eğitim; salgın sonrasında teknolojinin yaygınlığı, çevrimiçi eğitimin eğitim- öğretim faaliyetlerine kattığı çeşitlilik ve farklılık sebebiyle devam etmeli görüşünün yanı sıra her öğrencinin teknolojik donanım ve altyapıya sahip olmaması nedeniyle de devam etmemeli görüşü öne çımıştır. Her ne kadar Millî Eğitim Bakanlığı EBA Destek noktalarıyla ve ücretsiz tablet dağıtarak dijital erişim imkânı olmayan öğrencileri desteklemeye çalışsa da kırsalda bulunup İnternete bağlanamayan, ekonomik geliri yetersiz olan öğrencilere farklı projelerle uzaktan eğitime erişim fırsatı verilmelidir. Sarı (2020), uzaktan eğitimin niteliğini artırmak için okul öncesinden lisansüstü eğitime kadar her kademede uzaktan eğitim uygulamalarında altyapının oluşturulması gerektiği sonucuna varmıştır. Bu sonuç çalışmanın sonucuyla benzer niteliktedir.

Uzaktan eğitimin LGS başarısını her öğrencinin teknolojik donanım ve altyapıya sahip olmaması, öğrencilerin salgından olumsuz etkilenerek çalışmayı bırakması ve okuma becerilerindeki gerileme sebebiyle olumsuz etkileyeceği düşünülmektedir. Dönem dönem 8.sinıflarda yüz yüze eğitim devam ettiği için öğrencilerin süreçten etkilenmeyeceğini düşünenler de vardır. Çeşitli sebeplerle uzaktan eğitim faaliyetlerinin yoğun olduğu dönemler için öğrenci başarısını ölçme ve değerlendirmede yüz yüze eğitim döneminden farklı alternatif ölçme ve değerlendirme yaklaşımı, sistematik bir şekilde

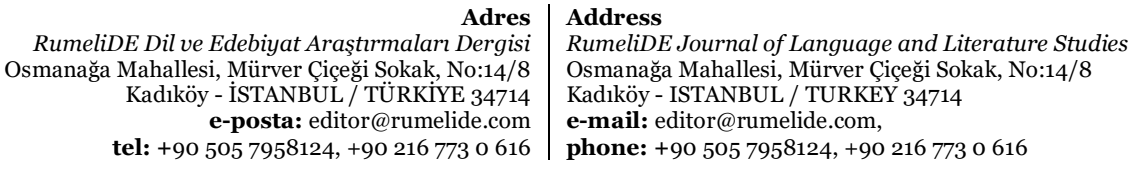


oluşturulmalı ve kriz durumunda öğrencilerin başarısı söz konusu yaklaşıma göre değerlendirilmelidir. Can (2020), salgın sürecinde ölçme değerlendirme konusunun daha sistematik ele alınması gerektiğini vurgulayarak çalışmanın sonucu ile benzer bir sonuca varmıştır.

Sonuç itibarıyla kritik bir dönemde rol alan uzaktan eğitimin eğitim- öğretim faaliyetlerine sağladığı pek çok katkı bulunmaktadır. Öğrencilerin eğitim- öğretim faaliyetlerinden uzak kalmaması, bireysel öğrenmeyi desteklemesi, zaman ve mekândan bağımsızlık bu katkılardan bazılarıdır. Bununla birlikte motivasyon kaybına sebep olma, fırsat eşitsizliği oluşturma, altyapısal problemler, dönüt akışındaki eksiklik, teknoloji okuryazarlığındaki yetersizlik, sosyalleşmede eksiklik, uygulama içeren dersler için uygun olmama gibi birtakım olumsuz yönleri de bulunmaktadır. Barındırdığı olumlu ve olumsuz özellikleri ile uzaktan eğitimin tek başına yeterli olamayacağı ancak yüz yüze eğitimin önemli bir tamamlayıcısı olduğu açıtır. Uzaktan eğitimin tamamlayıcı görevini yürütebilmesi için altyapıya dayalı eksiklikler giderilmeli, eğitim sürecinin tüm paydaşlarını içine alacak teknoloji okuryazarlığı eğitimi verilmeli, uzaktan eğitimin niteliğine uygun materyaller üretilmeli, ölçme değerlendirme yöntemi uzaktan eğitim kapsamında gözden geçirilmeli, ekran bağımlılığı konusuna dikkat edilerek hem öğrencilerin hem de öğretmenlerin mekanikleşmesi engellenmeli, ayrıca öğrenci ve veliler İnternet okuryazarlığı kapsamında zararlı içeriklere karşı bilgilendirilmelidir.

\section{Kaynakça}

Aktaş, Ö., Büyüktaş, B., Gülle, M., \& Yıldız, M. (2020). Covıd-19 virüsünden kaynaklanan izolasyon günlerinde spor bilimleri öğrencilerinin uzaktan eğitime karşı tutumları. Sivas Cumhuriyet Üniversitesi Spor Bilimleri Dergisi, 1(1), 1-9.

Alakoç, Z. (2001). Genel olarak uzaktan öğretim ve konuya öğretim üyelerinin bakış açıları. Sakarya Üniversitesi Eğitim Fakültesi Dergisi, 3, 403-413.

Alpaslan, M. (2020). Öğretim üyelerinin özel yeteneklilerin eğitiminde uzaktan eğitimin kullanımına yönelik görüşleri. Açıöğ retim Uygulamaları ve Araştırmaları Dergisi, 6(1), 126-147.

Attri, A. K. (2012). Distance education: problems and solutions. International Journal of Behavioral Social and Movement Sciences, 1(4), 42-58.

Bawa, P. (2016). Retention in online courses: exploring issues and solutions $-A$ Literature Review. SAGE Open, 6(1), 1-11.

Bayburtlu, Y. S. (2020). Covid-19 salgın dönemi uzaktan eğitim sürecinde öğretmen görüşlerine göre Türkçe eğitimi. Turkish Studies, 15(4), 131-151.

Birkök, M. (2006). Uzaktan eğitimin sosyolojik kavramlarla analizi. Uluslararası İnsan Bilimleri Dergisi, 8(1), 1-8.

Can, E. (2020). Coronavirüs (Covid-19) salgını ve pedagojik yansımaları: Türkiye'de açık ve uzaktan eğitim uygulamaları. Açıköğretim Uygulamaları ve Araştırmaları Dergisi, 6(2), 11-53.

Chan, S. S., So, W. K., Wong, D. C., Lee, A. C., \& Tiwari, A. (2007). Improving older adults' knowledge and practice of preventive measures through a telephone health education during the SARS epidemic in Hong Kong: A pilot study. International Journal of Nursing Studies, 44, 1120-1127.

Creswell, J. W. (2013). Nitel araştırma yöntemleri: beş yaklaşıma göre nitel araştırma ve araşttrma deseni. Ankara: Siyasal Kitabevi.

Edelhauser, E., \& Lupu-Dima, L. (2020). Is Romania prepared for elearning during the covid-19 pandemic. Sustainability, 12(13), 1-29.

Eroğlu, F., \& Kalaycl, N. (2020). Üniversitelerdeki zorunlu ortak derslerden Türk dili dersinin uzaktan ve yüz yüze eğitim uygulamalarının karşılaştırılarak değerlendirilmesi. Ana Dili Eğitimi Dergisi, $8(3), 1001-1027$.

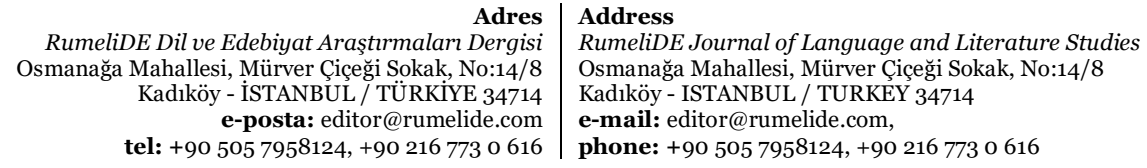


Erturgut, R. (2008). İnternet temelli uzaktan eğitimin örgütsel, sosyal, pedagojik ve teknolojik bileşenleri. Bilişim Teknolojileri Dergisi, 1(2), 79-85.

Fidalgo, P., Thormann, J., Kulyk, O., \& Lencastre, J. A. (2020). Students' perceptions on distance education: A multinational study. International Journal of Educational Technology in Higher Education, 17(18), 1-18.

Fidan, M. (2020). Covid-19 belirsizlĭğinde eğitim: İlkokulda zorunlu uzaktan eğitime ilişkin öğretmen görüşleri. Uşak Üniversitesi Eğitim Araştırmaları Dergisi, 6(2), 24-43.

Gewin, V. (2020). Five tips for moving teaching online as covid-19 takes hold. Nature, 580(7802), 295296.

Hiltz, S. R., \& Shea, P. (2005). The student in the online classroom. S. R. Hiltz, \& R. Goldman (Ed.) Learning together online: Research on asynchronous learning networks içinde (s. 145-168). Mahwah: Lawrence Erlbaum Associates.

Hotaman, D. (2020). Online eğitimin başarısı açısından biçimlendirici değerlendirmenin önemi. Uluslararası Sosyal Araşttrmalar Dergisi, 13(73), 729-738.

Karakuş, N., Ucuzsatar, N., Karacaoğlu, M. Ö., Esendemir, N., \& Bayraktar, D. (2020). Türkçe öğretmeni adaylarının uzaktan eğitime yönelik görüşleri. Rumelide Dil ve Edebiyat Araştırmaları Dergisi, 19, 220-241.

Kaya, Z. (2002). Uzaktan Eğitim. Ankara: PegemA Yayıncılık.

Keskin, M., \& Kaya, D. Ö. (2020). Covıd-19 sürecinde öğrencilerin web tabanlı uzaktan eğitime yönelik geri bildirimlerinin değerlendirilmesi. İzmir Kâtip Çelebi Üniversitesi Sağlık Bilimleri Fakültesi Dergisi, 5(2), 59-67.

Kocayiğit, A., \& Uşun, S. (2020). Millî Eğitim Bakanlı̆̆ına bağll okullarda görev yapan öğretmenlerin uzaktan eğitime yönelik tutumları (Burdur ili örneği). Avrasya Uluslararası Araştırmalar Dergisi, 8(23), 285-299.

Koç, E. (2020). Üniversite öğretim elemanlarının gözünden yüksek öğretimde uzaktan öğrenimin değerlendirilmesi. Akdeniz Üniversitesi Ĕ̆itim Fakültesi Dergisi, 3(1), 25-39.

Mahdy, M. A. (2020). The impact of covid-19 salgınc on the academic performance of veterinary medical students. Frontiers in Veterinary Science, 7(732), 1-22.

Özdoğan, A. Ç., \& Berkant, H. G. (2020). Covid-19 salgın dönemindeki uzaktan eğitime ilişkin paydaş görüşlerinin incelenmesi. Millî Eğitim, 49(1), 13-43.

Özyürek, A., Begde, Z., Yavuz, N. F., \& Özkan, İ. (2016). Uzaktan eğitim uygulamasının öğrenci bakış açısına göre değerlendirilmesi. Karabük Üniversitesi Sosyal Bilimler Enstitüsü Dergisi, 6(2), $592-605$.

Paepe, L. D., Zhu, C., \& DePryck, K. (2018). Drop-out, retention, satisfaction and attainment of online learners of Dutch in adult education. International Journal on E-Learning, 17(3), 303-323.

Ramos-Morcillo, A. J., Leal-Costa, C., Moral-Garcia, J. E., \& Ruzafa-Martinez, M. (2020). Experiences of nursing students during the abrupt change from face-to-face to e-learning education during the first month of confinement due to covid-19 in Spain. International Journal of Environmental Research and Public Health, 17(15), 1-15.

Sarı, H. (2020). Evde kal döneminde uzaktan eğitim: Ölçme ve değerlendirmeyi neden karantinaya almamalıyız. Uluslararası Eğitim Araştırmacıları Dergisi, 3(1), 121-128.

Serçemeli, M., \& Kurnaz, E. (2020). Covıd-19 salgın döneminde öğrencilerin uzaktan eğitim ve uzaktan muhasebe eğitimine yönelik bakış açıları üzerine bir araştırma. Uluslararası Sosyal Bilimler Akademik Araştırmalar Dergisi, 4(1), 40-53.

Taşlıbeyaz, E., Karaman, S., \& Göktaş, Y. (2014). Öğretmenlerin uzaktan hizmet içi eğitim deneyimlerinin incelenmesi. Ege Eğitim Dergisi, 15(1), 139-160.

Titmus, C. (1997). Yetişkin eğitimi terimleri sözlüğü. Ankara: UNESCO Türkiye Milli Komisyonu.

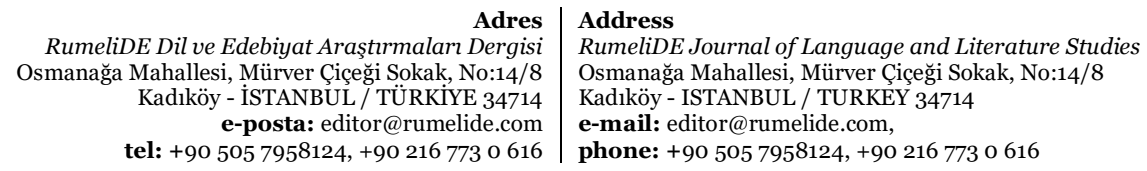


Ustabulut, M. Y. \& Keskin, S. (2020). 'Tele-education' in the COVID-19 process in Turkey: A mental diaspora research specific to Turkish teaching students. Journal of Language and Linguistic Studies, 16(4), 2163-2181.

Yıldırım, A., \& Şimşek, H. (2018). Sosyal bilimlerde nitel araştırma yöntemleri. Ankara: Seçkin Yayınevi.

Yılmaz, N. A. (2020). Yükseköğretim kurumlarında covid-19 salgınsi sürecinde uygulanan uzaktan eğitim durumu hakkında öğrencilerin tutumlarının araştırılması: Fizyoterapi ve rehabilitasyon bölümü örneği. Necmettin Erbakan Üniversitesi Sağllk Bilimleri Fakültesi Dergisi, 3(1), 15-20.

Yolcu, H. H. (2020). Koronavirüs (covid-19) salgın sürecinde sınıf öğretmeni adaylarının uzaktan eğitim deneyimleri. Açıköğretim Uygulamaları ve Araştırmaları Dergisi, 6(4), 237-250.

RumeliDE Dil ve Edebiyat Araştırmaları Dergisi Osmanağa Mahallesi, Mürver Çiçeği Sokak, No:14/8 Kadıköy - ÍSTANBUL / TÜRKIYE 34714 e-posta: editor@rumelide.com tel: +90 505 7958124, +90 2167730616
Address

RumeliDE Journal of Language and Literature Studies Osmanağa Mahallesi, Mürver Çiçeği Sokak, No:14/8

Kadıköy - ISTANBUL / TURKEY 34714

e-mail: editor@rumelide.com,

phone: +90 505 7958124, +90 2167730616 